\title{
Towards Stimulating Tools for Advancement of Environmental Conservation through Promoting of Psychological Instruments
}

\author{
Md. Rahimullah Miah ${ }^{1,3}$, Mohamed Sharif Mustaffa ${ }^{2}$, Samsiah Jayos ${ }^{2}$, Nor Hasniah Ibrahim², Sopian Bujang², \\ Jamayah Saili ${ }^{2}$ \& Alexander K. Sayok ${ }^{3}$ \\ ${ }^{1}$ Mornington University College, Amborkhana, Sylhet, Bangladesh \\ ${ }^{2}$ Faculty of Cognitive Sciences and Human Development, Universiti Malaysia Sarawak, Malaysia \\ ${ }^{3}$ Institute of Biodiversity and Environmental Conservation, Universiti Malaysia Sarawak, Malaysia \\ Correspondence: Dr. Md. Rahimullah Miah, Associate Professor and Education Coordinator, Mornington \\ University College, Sylhet, Bangladesh and awarded the PhD from Universiti Malaysia Sarawak, Malaysia. Tel: \\ 880-17-0419-8862; 880-17-6422-5555; 017-2047-7740. E-mail: 14010140@siswa.unimas.my
}

Received: May 31, 2019 Accepted: June 15, $2019 \quad$ Online Published: July 30, 2019

doi:10.5539/jsd.v12n4p196 URL: https://doi.org/10.5539/jsd.v12n4p196

The research is financed by the Zamalah Graduate Scholarship, Universiti Malaysia Sarawak (UNIMAS), Malaysia and PhD Fellowship from Information and Communication Technology Division (ICTD), Ministry of Posts, Telecommunication and Information Technology, Government of People's Republic of Bangladesh.

\begin{abstract}
The explorative field observation on Environmental Conservation Psychology (ECP) is multi-diversified with collective and conjectural outlook. ECP provides a better understanding of the way in which conservation awareness, attitude, ethics, culture and well-being are affected by physical environments, social settings and built-in environment. The goal is to stimulate more attention be paid to ensure the effectiveness of environmental conservation and highlight psychological instruments required to develop new interdisciplinary approaches with innovative ways in prevailing challenges for the present and upcoming generations. Primary data were collected from a sample of respondents at the Lawachara National Park (LNP) in Moulvibazar district of Bangladesh and secondary data were obtained from diverse sources. The research denoted and investigated by various disciplines and fields including environmental behaviors studies, positive psychology, person-environment studies, human-nature science and ecological psychology. The study showed about $70 \%$ of indigenous respondents opined on positive attitudes for environmental conservation to compare with $55 \%$ in others. The study identified approximately $65 \%$ of respondents stated for development of environmental education among local communities for promoting positive psychology surrounding the national park. This study focuses the importance of understanding this multidimensional psychological research as it is to inform about the environmental conservation perspectives that have contributed to and shaped the learning with high internal conservation stability, dependability, uniformity, and attractiveness with social bonding at LNP. This study represents the environmental design, manage, protect and restore conserving of biodiversity towards national parks that influence human behavior, predict and the likely outcomes when these conditions are not met and diagnose problem situations. This study links at solving complex environmental conservation problems in the pursuit of individual well-being within a longer community through human-environment conservation interactions.
\end{abstract}

Keywords: positive psychology, human-nature science, stimulating factors, human behaviors

\section{Introduction}

Global environmental conservation problems of shrinking natural resources, pollution and population growth challenge the ways people live. People are the main factor of all problems while people are the effective solutions for nature conservation. As a whole with many other disciplines, psychology attempts to develop human societies less exploitive in their use of the earth's natural resources (Stern, 1992a, Kruse, 1995). However, psychologists refer to individual behavior rather than to behavior of whole societies they ask questions such as what determines an individual's ecological behavior, i.e. 'actions which contribute towards environmental conservation and or protection (Axelrod \& Lehman, 1993) or how behavior can be changed in a more ecological 
direction. In responding these questions, environmental conservation attitude is considered on the most promising concepts (Newhouse, 1990). Almost the relationship between environmental conservation attitude and ecological behavior is well-explored in modern era. Therefore, the reciprocal relationship appears to be at best moderate across various studies (Hines et al., 1986). This lack of a stronger correlation occasionally results in rather pessimistic views of the usefulness of environmental attitude as a predictor of ecological behavior (Stern, 1987, Lloyd, 1980). The present study promotes the theory of planned behavior (Ajzen, 1985 \& 1991), as an overall theoretical framework in the ecological domain. Moreover, both of the methodological shortcomings can be overcome using a probabilistic measurement approach for the assessment of ecological behavior. A lack of consciousness with the scope and uncertainty about the environmental conservation purpose impedes the community's engagement with the human dimensions (Bennett et al., 2017). Environmental social science and human dimensions of natural resource management can be viewed as similar and overlapping traditions (Cox, 2015; Moran, 2010; Vaccaro et al., 2010; Wellman et al., 2014; Clark et al., 2008; Decker et al., 2012; Gorenflo and Brandon, 2006). The update research has also required assimilating social and ecological concerns into biodiversity conservation (Kittinger et al., 2012; Manfredo et al., 2014a, 2014b). Environmental conservation psychology (ECP) is the combination of environmental science, conservation science and human behavior, attitude and perceptions. ECP can be defined as the discipline that studies the interplay between individuals and their built-in and natural environment (Steg et al., 2013). ECP is an interdisciplinary area that provides in the interplay between individuals, association and their environments. The area defines the term environment conservation broadly - encompassing natural environments, social settings, built environments, learning environments, conserving biodiversity and informational environments. According to the conception, the area has been committed to the development of a disciplinary, which is integrated the value oriented and problem oriented prioritizing research aimed at solving complex environmental problems in the pursuit of individual well-being within a larger society (Proshansky, 1987). When a solving problem involving human-environment interactions, whether global, regional or local, one must have a framework of human-environment-nature that predicts the environmental conditions under which humans can contribute well. This framework can help to identify, design, manage, ornament, protect and restore environments that enhance reasonable psychological behavior, predict the likely outcomes when these conditions are not met, and diagnose problematic situations. The research area develops such a framework of human-environment nature while retaining a broad and inherently multidisciplinary focuses particularly biodiversity conservation. It represents relevant dissimilar circumstances as common property natural resource management, way finding in complex settings, the effect of environmental conservation stress on human performance, the characteristics of conserving biodiversity, human information processing and the promotion of durable conservation behavior.

Moreover, towards the augmented focus on loss of biodiversity, over-exploitation, misuse emerging technology to iconic biodiversity, climate change in society, the social sciences and the re-emergence of limit-to-growth concerns, there has been increased focus on environmental sustainability issues within the area (De Young, 2013). Environmental conservation psychology is expected to develop dynamic characteristics with multidisciplinary paradigm. It can contribute as a catalyst in attracting other schools of knowledge in its pursuit, aside from research psychologists. Environmental psychologists, geographers, economists, landscape architects, policy-makers, sociologists, anthropologists, educators, conservationists, biodiversity specialists, and product developers all have discovered and participated in this area (Proshansky, 1987). Environmental conservation psychology is arguably the best-known and most comprehensive description of the research arena. It is also known as human factors science, cognitive ergonomics, ecological psychology, eco-psychology, environment-behaviour studies and person-environment studies. Closely related fields include architectural psychology, socio-architecture, behavioral geography, environmental sociology, social ecology, and environmental design research. This research establishes environmental conservation attitude, awareness and perception as a powerful stimulator of ecological behavior. Earlier research has failed in these perspectives due to lack of a unified concept of attitude, less measurement correspondence between attitude and behavior in general level and behavioral constraints beyond humans' control. The study identified three measures as orthogonal dimensions by means psychological tools analysis, such as: environmental conservation knowledge, conservation values and conservational behavior intention.

\section{General Context of the Study}

Human beings are the source of diversified problems whether the hope of dynamic solutions. A new field of environmental conservation psychology is recognized to make stronger networks between the natural and social sciences, between research and practice, and between psychology and other social sciences (Saunders, 2003). Biodiversity is in the core field of environmental issues which connect with conservation psychology. The 
problem of loss of biodiversity has been raised as a very important global issue for several years due to the lack of dynamic policies, technological applying, institutional support and stakeholder engagement. All these phenomena are connected with human behaviors, attitudes, perceptions, integrity, identity and cultural perspectives. Therefore, environmental conservation psychology (ECP) is to conduct biological conservation and psychological research which is directly integrated towards the aims of environmental conservation sustainability. Its importance is diverse and multi-facet at national and global periphery to compare with other fields, such as (i) biological conservation, (ii) environmental psychology, (iii) human behavioral science and (iv) anthropological science. The major functions of ECP are:

$\checkmark$ To motivate people to act in more environmentally-friendly conservation ways.

$\checkmark$ Encouraging people to care about the natural world and their role in connection with their environments.

$\checkmark$ To enhance the dynamic process by which psychologists, social scientists and practitioners identify high-priority research question which is connected with ECP.

$\checkmark$ To provide the experts in human behavior, psychologists and conservationists on various approaches for recognizing the cognitions, attitudes, motives, beliefs, values, identity and types of behaviors related to environmental conservation issues.

$\checkmark$ To focus at the individual levels can underemphasize the relevant important causes and solutions of environmental problems, for examples- individuals or group or social systems or biggest threats to environmental degradation occur at the level of relevant organizations, which is linking developments in organizational theory with corporate environmentalism, conservationism, and environmental conservation policy.

$\checkmark$ To provide the idea of helping people a sustainable and harmonious relationship with nature through recreation, conservation education and discovery of biological knowledge (Cranston, 2016).

\subsection{Historical Background of ECP}

Environmental conservation psychology is the new theme with multidisciplinary field of study including environmental conservation and psychological options. The main field of study is not disseminated broadly, however, Willy Hellpach mentioned " environmental psychology" of his book, Geopsyche, discusses topics on 'the sun and the moon affect human activity', the effect of extreme environments, and 'the impact of colour and form' (Pol, E., 2006). Other main scholars stated the source of environmental psychology with their diverse contribution Among the other major scholars at the roots of environmental psychology were Jacob von Uexkull, Kurt Lewin, Egon Brunswik, and later Gerhard Kaminski and Carl Friedrich Graumann (Christian, 2003). The end of World War II brought about a higher demand for developments in the field of social psychology particularly in the areas of attitude change, small group processes and intergroup conflict. This demand caused psychologists to begin applying social psychology theories to a number of social issues such as prejudice, war and peace. It was thought that if these problems were addressed, underlying notions and principles would surface Although this period was crucial to the development of the field, the methodologies used to carry out the studies were questionable. At the time, studies were being conducted in a laboratory setting, which caused some doubt as to their validity in the real world. Fact and reality anticipated with diverse historical attitudes to environmental conservation sustainability from traditional to modern humans' behavior. Using psychological values in exercise through accepting the history of ECP is fundamental to the efficient manifestation of its future potential. Walking through the institutions in lab court propagates to the community's perception and a deeper appreciation for potential of ECP developed (Cranston, 2016). Having a vibrant representation of how psychological theory was instigated as a real-world tactic to environmental conservation sustainability in the past might compromise future environmental psychologists and researchers a representational instruction guide for ECP's upcoming implementation.

\subsection{Biodiversity Conservation and Psychological Stimulation Perspectives}

Biodiversity is the variety and variability of living organisms (CBD, 1992). National parks (NPs) are instrumental in supporting biodiversity conservation while providing many benefits to the society. Globally, these benefits are on an increase. Their management requires consideration of their multiple functions to enable combination of relevant ecological, psychological, economic and social aspects (Liaison Unit Vienna, 2000). The $113,000 \mathrm{NPs}$ and similar protected areas in the world cover approximately $6 \%$ of the Earth's land surface (Ceballos et al., 2015), covering some 149 million square kilometres (NPFF, 2016). In the Asian region, there are 10,900 protected areas covering $13.9 \%$ of the terrestrial environment and $1.8 \%$ of the marine and coastal areas 
(Juffe et al., 2014). These protected areas, unfortunately, are under threat and losing biodiversity rapidly. The main threats to these protected areas are over-exploitation of biodiversity due to high population density and increasing demands from a globalised markets, as well as habitat loss and degradation in adjacent areas. Additional problems are now emerging which are particularly difficult to solve (Lafferty and Meadowcroft, 1996; Weale, 1992). Among them are excessive invasive alien species, over exploitation, deforestation, poverty, fragmentation and illegal wildlife trade, man-made fire and other interferences that urgently need to be addressed (Juffe et al., 2014). Biodiversity and national parks interlink with environmental conservation psychological tools as courses of action which are intended to influence the national park community (Lundqvist, 1996). Conserving of Biodiversity is the idealistic agenda of global environmental concerns, which is a unique variety of life (Wilson, 1988) for stimulating phenomena on our planet. This biodiversity underpins national economy and well-being (EC, 2015) to conserve present and upcoming generations. Biodiversity is the multiplicity and changeability of living flora then fauna in sphere. It is a multifaceted word, which indicates its specific objective as the changeability amongst alive creatures starting entirely home environment comprising, and so on, land-dwelling, sea as well as additional river ecologies and the environmental multiplexes of their apart; this embraces variety surrounded by species (Soulé and Sanjayan, 1998), concerning species and of environmental conservation (CBD, 1992). Human-beings live in the age of information with modernized technology (Kinuthia, 2008), which enhances the production, storage, cognition and sharing of information with rules and regulations to make a significant facet of economic, cultural and scientific affairs at scales from local to global (Michael et al., 2006) biodiversity information, which stimulates environmental conservation perspectives.

\subsection{Stakeholders' Perception and Evidence-Based Conservation}

The psychology is the branch of conservation science as the scientific study of scientific thought or behavior of stakeholders (Simonton, 1988). Stakeholders are an integral part of evidence-based conservation (Theobald and Hobbs, 2002), who provide four important functions, such as:

(i) Stakeholders establish conservation goals.

(ii) Stakeholders are able to frame and refine the spatial modelling process

(iii) Stakeholders help to assemble a list up to twelve alternative build-out scenarios.

(iv) Stakeholders filter the preliminary list of indicators for conserving of biodiversity.

(v) Stakeholders connect the psychological behavior with environmental conservation in the society.

Regulation makes some products more exclusive to enable consumers to buy the products at their higher prices (Portney, 1990). The regulations enhance to stakeholders, who are: (i) Development Sectors, (ii) Biodiversity experts, (iii) Forest manager, (iv) Ecologists, (v) Environmental conservationists, (vi) Environmental education think-tank, (vii) Policy-makers, (viii) Park managers, (ix) Judges, (x) Environmental lawyers, (xi) Academics, (xii) Biodiversity information system managers, (xiii) Collaborative team leaders, and (xiv) Local villagers and indigenous people, (xv) Conservation psychologists (Tyrrell and Alcorn, 2011). National Park's biological diversity is a landscape perception, although its preservation is some multidimensional problems (Elliott, 1994) connecting with various local and global stakeholders for natural resources management, sustainable use and security at a wide-range of rules and regulations. These regulations provide informative evidence (Sutherland et $a l ., 2004)$ that supports for formulation, evaluation and decision-making towards evidence-based national park biodiversity management (Bennett, 2016). Several research and reviews represent that the execution of biodiversity protection and security is no promise of conservation achievement (Edgar et al., 2014; Pfeifer et al., 2012; Ferraro et al., 2013; Mora and Sale, 2011), otherwise, of advantage towards individuals (Bennett and Dearden, 2014a; Coad et al., 2008; West et al., 2006); on the way to national park. Operative protection for resolutions from side to side co-management comprises a sequence of management planning outcomes (Hockings et al., 2006). Except co-management with local and indigenous peoples' involvement, the conservation scheduling including checking and evaluating (Bennett and Roth, 2015) are not guaranteed for suitability and backing for commendations (Chevalier and Buckles, 2013; Fortmann, 2008; Evans and Guariguata, 2008; Gujit, 1999). These local and indigenous communities support relevant models of caring species richness of national parks (McNeely, 1994) as well as biodiversity conservation perspectives (Bennett \& Dearden, 2014a). The achievement of national park biodiversity management through local people's (MacKinnon et al., 1986) participation enhances in desired condition (Ali and Habib, 1998) as well as establishing co-management (Poffenberger, 2000). However, collaborative management is integrated with local people (MEA, 2005), indigenous people, elite leader, local government leader, decision-maker and administrative body for national park's biodiversity management. 


\section{Methodological Approaches}

Human-focused approach to environmental conservation sustainability reflected an important role in the emergence of what would later be considered a pioneering reliability of environmental conservationists, psychologists, researchers and practitioners with the collective goals. Methodological approach is the process of data collection, compilation, integration, analysis and interpretation of the environmental conservation findings. This approach is suitable for the collection of environmental conservation data on the priority of psychological factors including perception, awareness, attitude, opinion and involvement of community people adjacent national park area.

\subsection{Study Site and Data Collection}

The study was undertaken with different methodological approaches particularly Lawachara National Park (LNP) at Kamalganj sub-district in Moulvibazar of Sylhet division, Bangladesh coordinates with $24^{\circ} 32^{\prime} 12^{\prime \prime} \mathrm{N}$ $91^{\circ} 47^{\prime} 03^{\prime \prime} \mathrm{E}$ (NSP, 2005) as the biodiversity conservation case study site, as shown in Figure 1 (MP, 2006). The LNP is one of three national parks in Sylhet region in the northeastern part of Bangladesh (RIMS, 2015).

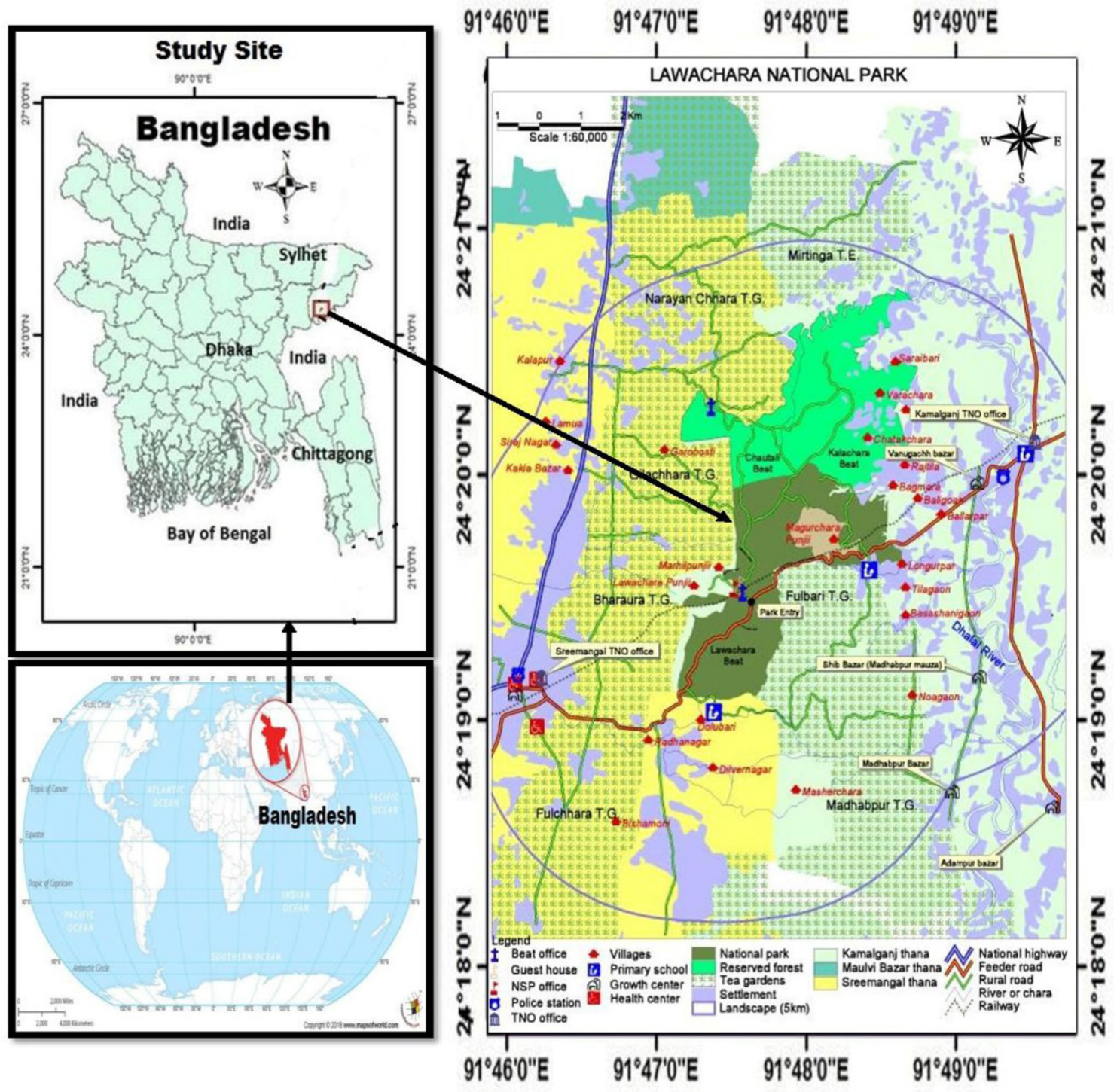

Figure 1. Map of Study Area- Lawachara National Park, Moulvibazar district of Bangladesh

It is semi-evergreen and mixed deciduous forest (Champion et al., 1965). Total 460 species consist of floral 167 and 293 faunal species including amphibian 4, reptiles 6, birds 246, mammals 20, insect 17 (IPAC, 2012; Jalil, 2009). Major plant species are Chapalish, Gorjon, Jarul, Rokton, Segun and major wildlife species are Macaque, 
Barking deer, Capped Langur (NSP, 2006). The Lawachara is the most suitable to tourists to watch the stunning Hoolock Gibbon (Bunipithecus hoolock / Hylobates hoolock)), Capped Langur (Trachypithecus pileatus), Phayre's Langur (Trachypithecus phayrei), Pigtailed Macaque (Macaca nemestrina), Orange-bellied Himalayan Squirrel (Dremomis lokriah), Barking Deer (Muntiacus muntjac), Masked Civet (Paguma larvata) and rare Cobra and Python species (NACOM, 2003; Hossain, 2007). The LNP is an attractive ecotourism destination due to its aesthetic scenary and dense forest diversity (NSP, 2006). The Park was also a hotspot for biodiversity to find several species of a new and regional record for biodiversity conservation of Bangladesh (Hossain, 2001; Rufford, 2014). For this purpose, the methodological approach was connected with different parameters to enhance primary and secondary data collection, compilation and interpretation. This approach supports to environmental conservation psychology related data integration, data compilation, and analysis and model development related to biodiversity conservation, psychological instruments and decision making processes. This research approach was connected with the whole research procedure including primary and secondary data collection on the priority of qualitative and quantitative data (Kothari, 2004). The research method uses for raw and original data collection related to biodiversity conservation, environmental identity, attitude, perception, awareness and stakeholders' involvement towards stimulating National Park's biodiversity conservation. This research included its philosophy, approach, strategy, and time horizon with collected data sample size. The average sample size is $30.36 \%$ with respondents' rate which as shown in Table 1.

Table 1. Status of respondents in the studied area

\begin{tabular}{lrrrr}
\hline Name of village & $\begin{array}{c}\text { Existing Households } \\
\text { (NSP, 2006) }\end{array}$ & $\begin{array}{c}\text { Total Existing } \\
\text { Member }\end{array}$ & $\begin{array}{c}\text { Number of } \\
\text { Respondents }\end{array}$ & Respondent's rate (\%) \\
\hline Lawachera Punji & 23 & 116 & 29 & $25 \%$ \\
Magurchera Punji & 41 & 165 & 48 & $29 \%$ \\
Dolubari & 84 & 255 & 46 & $18 \%$ \\
Langurpur & 92 & 278 & 83 & $30 \%$ \\
Total & 240 & 814 & 206 & $25.5 \%$ \\
Other Respondents & & 247 & 87 & $35.22 \%$ \\
Grant Total & & 1061 & 293 & $30.36 \%$ \\
\hline
\end{tabular}

Besides, the rest of respondents are 87 including visitors, biodiversity specialist, forest officer, biologist, agriculturalist, ecologist, conservationist, environmentalist, psychologists, policy-maker, botanist, zoologist, wildlife manager, co-management team leader, judges, environmental lawyer, indigenous community leader, academicians and NGO officers. All collected data compiled with statistical software for analysis, interpretation and psychological explore.

\subsection{Data Analysis and Interpretation}

The research method was associated with different parameters to enhance data collection, compilation, analysis and interpretation. Quantitative and qualitative related environmental psychology data were obtained through field observation, interviews, field surveys, focus group discussions, and informal discussion while secondary data were obtained from diverse sources with environmental psychology assessment method. The data were compiled and analyzed for presentation and interpretation using standard data analysis software like MS Office Suite 2016.

\section{Results}

From the field observation, psychological instruments enable to promote the conserving of biodiversity towards Lawachara National Park. These are included (i) conservation awareness, (ii) attitudes, (iii) collaboration, (iv) environmental education, (v) visitor's satisfaction, (vi) local settlement, (vii) place attachment, (viii) indigenous people involvement, (ix) gender participation, (x) integration of stakeholder, (xii) human-biodiversity interaction, (xii) socio-culture, (xiii) community association, and (xiv) media exposure. The findings of some of the psychological instruments are illustrated as below successively.

\subsection{Environmental Conservation and Psychological Behaviors}

There is a reciprocal relationship between environmental conservation and psychological behavior for 
stimulating national park biodiversity protection. The main findings from field descriptions showed that inhabitants of four villages (Lawachera punji, Magurchera punji, Dolubari and Langurpur) were highly dependent on natural resources of Lawachara National Park (LNP). Due to this high dependency on the national park resources, most of the respondents in four villages admitted to undertake illegal as well as unwanted activities inside the park. For example: illegal logging, poaching, hunting, illicit-felling, encroaching (Reuters, 2007). However, the response patterns from interviews and key informant interviews in four villages indicated that more than $50 \%$ of the respondents believed in conservation of LNP's biodiversity. Most of them wished to see the LNP and conserved well according to environmental conservation status, attitude, perception and awareness.

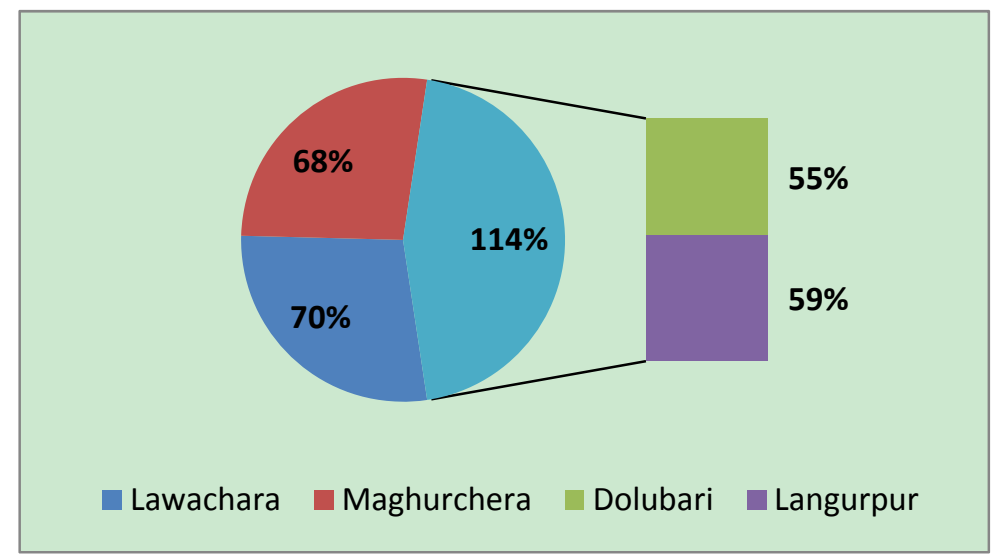

Figure 2. Positive attitudes among different household's response rate

The positive attitude of them could be related to the benefits earned from the LNP, which include incomes from the ecotourism services, employment opportunities, and enjoyment of viewing wildlife and pertinent values for present and upcoming generations. The management of biodiversity by security representative and well-connected habitat network in managed national parks. The park requires a wise combination of protection, maintenance, restoration and stimulation of plants, animals and habitat at sustaining goals (Angelstam et al., 2003). The ultimate goal of this research is to evaluate the existing laws, policies, assessment of biodiversity conservation systems with psychological factors and stakeholders' engagement, control measures of invasive alien species and conservation strategies. The socio-economic data on positive attitude towards National Park Biodiversity Conservation 63\% (average) illustrated with individual village respondent's opinion (Figure 2). With detail to earlier survey assumed in the National Park /environmental area, this mentioned outcome is reasonably acceptable for a field assessment.

\subsection{Psychological Conservation Awareness among Stakeholders}

Socio-economic features enhance to identify the different parameters of stakeholders for co-operation and management of National Park biodiversity, as shown in Figure 3. The graph represents different types of stakeholders who responded in the research activities in connection conservation. 


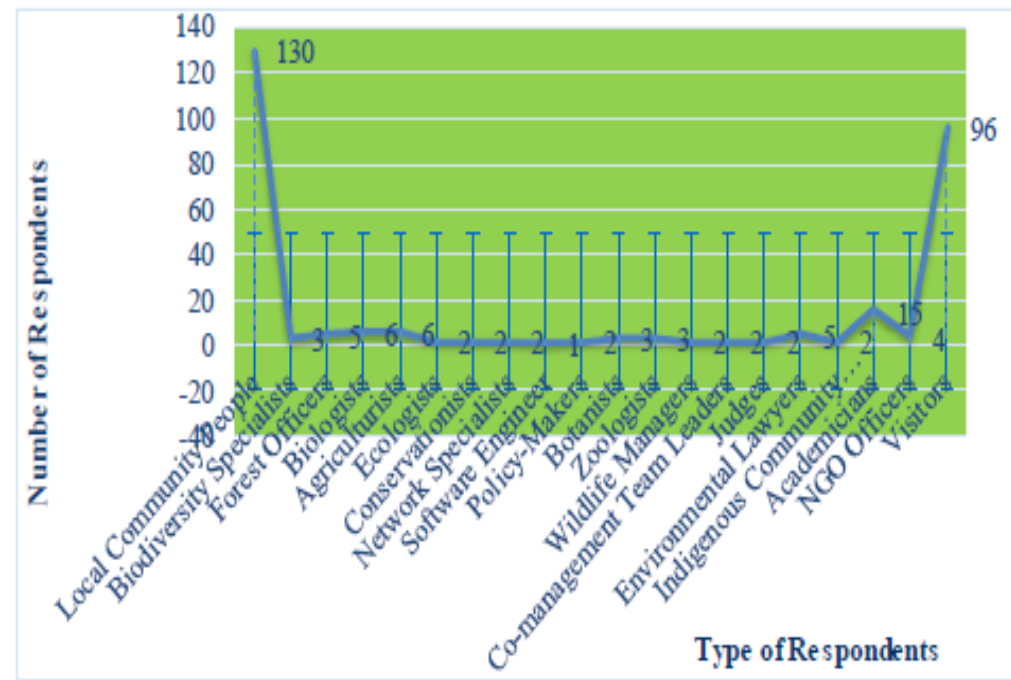

Figure 3. Using psychological factors with quantity of respondents

Most of stakeholders (110) are responded as local people, visitors (96) and minimum (1) respondent is national policy-maker. From the study, it found that the educationist and researcher are statistically significant. These stakeholders contribute their consciousness towards national park biodiversity conservation through accompanied with primary, secondary and tertiary stakeholders on the priority of positive psychology.

These stakeholders are aware on biodiversity conservation at Lawachara National Park, which as shown in Figure 4.

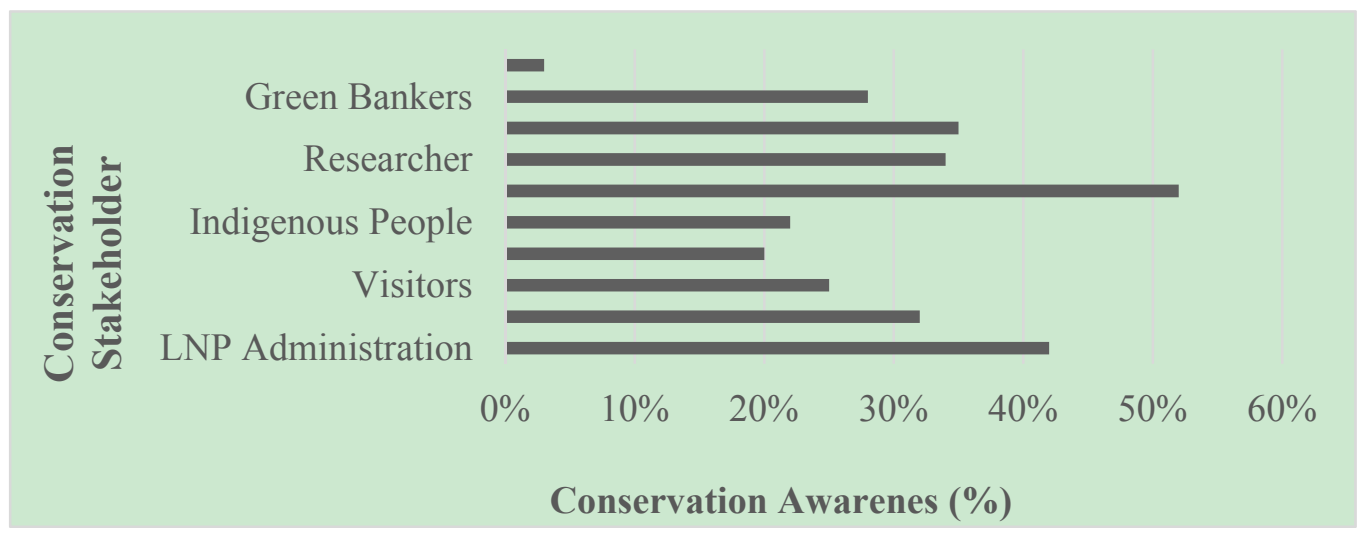

Figure 4. Stakeholders' conservation awareness

The study found that NGOs and development organizers are more aware (52\%) but local villagers $(20 \%)$ are less motivated than others. It depends upon the participation of all the stakeholders for proposing activities of administration, private sector, non-governmental organizations, environmental conservation psychologists, local and indigenous community leaders. Settlement has been one of the main footprints of humanity on earth's terrestrial ecosystems (Massada et al., 2014).

\subsection{Community Settlement with Place Attachment}

Lawachara National Park is the park area in which human settlements adjoin or intermix of local and indigenous communities with bio-ecosystems. These human settlements affect neighboring ecosystems through biotic processes including introduction of exotic species, wildlife subsidization, land encroachment, disease transfer, land cover conversion, fragmentation, and habitat losses. In this LNP, there are numerous interactions between human and natural resources as a bio-ecologically region in Bangladesh. The effects of LNP settlements on biodiversity conservation are two tiered- starting with national park modification and fragmentation by railway route and vehicle road, and progressing on different processes in which direct and indirect effects of anthropogenic activities spread into neighboring ecosystems at varying fluctuate scales. Lawachara National 
Park (LNP) surrounded by 18 villages, tea-estate, agricultural land and barren land. The people of these villages are dependence on LNP including major, moderate and minor primary stakeholders according to involvement and distance. Inhabitants of Lawachera, Magurchera, Dolubari and Biranpur are involved in fuel wood collection from Lawachara National Park, while the people of Bagmara, Radhanagar, Rashtila, Baligaon, Verachera and Chatakchera villages are involved in illicit tree felling at the park. Out of six Tea-estates, Noorjahan and Bharaura are neighbouring tea-estate and the rest of tea-estates are country bordering. The employed tea-estate workers and their families are involved in illegal logging (NSP, 2006) from within LNP.

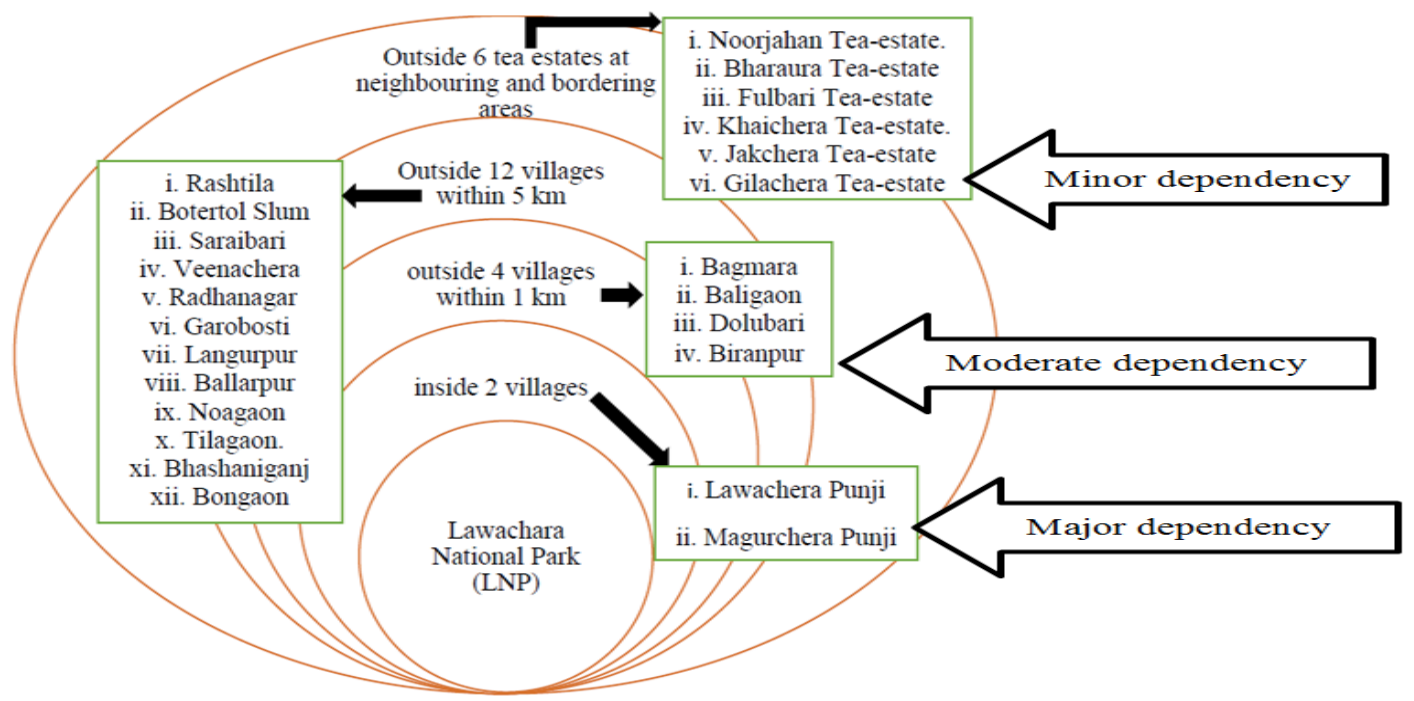

Figure 5. Place attachment towards Lawachara National Park and adjacent villages

The study suggested that need environmental education programme for awareness building among the communities of two inside and four outside villages. New scientific management and conservation psychological tools needed in order to better consciousness the LNP as a unique social-ecological zone and to mitigate negative consequences of its sustainable management. The study identified the following outputs drawing upon the psychological place attachment theory (Figure 5), which are attached villages surrounding the LNP.

(a) Major dependency villages: Bagmara, Magurchera, Lawachera, Baligaon, Dolubari and Biranpur. These villages are situated within $1 \mathrm{~km}$ surrounding LNP.

(b) Moderate dependency villages: Rashtila, Botertol Slum, Saraibari, Veenachera, Radhanagar and Garobosti;

(c) Minor dependency villages: Langurpur, Ballarpur, Noagaon, Tilagaon, Bhashaniganj and Bongaon.

Researchers recognize that place attachment is a multidimensional paradigm including place attendance, place identity, place affect and social bonding (Hidalgo \& Hernandez, 2001; Scannell \& Gifford, 2010a; Stokols \& Shumacker, 1981; Prohansky, 1978; Kals \& Maes, 2002; Scannell \& Gifford, 2010a, 2010b). Role of community place attachment on for conservation awareness is positive perception (Cheung and Hui, 2018). There is a reciprocal relationship between community settlement and place attachment for conserving of national park biodiversity.

\subsection{Environmental Conservation Awareness}

From the field survey, the community environmental awareness seems to decrease on the priority of respondents' reflection, acceptance and need basis, as shown in Figure 6. The most $65 \%$ respondents' expressed their opinion on augmenting environmental education programs, like systematic curriculum development, scientific action-oriented programs, empirical education, enthusiastic to digital conservation, ecological field exposures, sectoral integration and academia trainings, institutional green activities and conservational motivation. The study approached the protection of biodiversity from a biological, psychological or educational perspective focusing primarily on using knowledge of the complexities of wildlife and national park to strengthen conservation efforts (Cranston, 2016). 


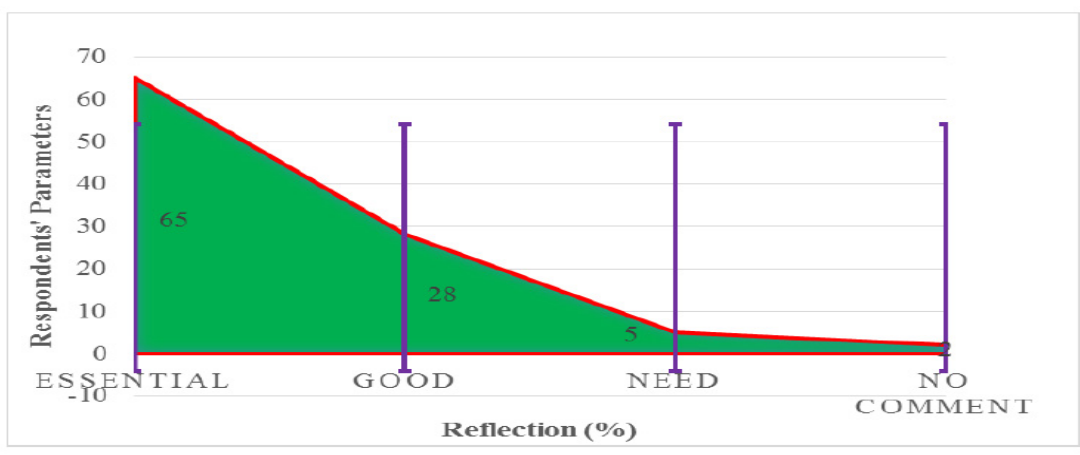

Figure 6. Augmenting environmental education adjacent national park areas

\subsection{Environmental Conservation Psychology Related Gaps Analysis}

Environmental conservation psychology highlights on the study of human thought related the natural environment and conservation pertinent subject matters and its influence on human behaviors. The highlight is on the individual regarding perception, awareness, values, attitudes, beliefs, norms and emotions in connection with the context of social groups (Clayton and Myers, 2015; Manfredo, 2008; Saunders, 2003; Vaske and Manfredo, 2012). Conservation related policies contain some gaps on biodiversity protection, environmental education, effective management, cooperation, coordination and integration among various sectors/departments. Corresponding to the magnitude and diversity of environmental challenges facing humanity at present, the field of conservation psychology spans very broadly, encompassing the study of human-animal and human-nature relationship, significant life experiences in developing environmental concern, environmental education, environmental values, norms, attitudes and actions, which are illustrated with key concepts, theories, and research focuses in Table 2.

Table 2. The behavioral status of environmental psychology and their factors

\begin{tabular}{|c|c|c|c|}
\hline $\begin{array}{l}\text { Behavioral } \\
\text { parameters }\end{array}$ & Behavioral response & Human-nature interactions & $\begin{array}{l}\text { Achieve Ideas on environmental } \\
\text { conservation issues }\end{array}$ \\
\hline $\begin{array}{l}\text { Conservation } \\
\text { Perception }\end{array}$ & Commonsense & Theories of persuasion & $\begin{array}{l}\text { Reflective environmental conservation } \\
\text { knowledge sharing }\end{array}$ \\
\hline Psycho-social values & Selecting target behaviors & Bio-environmental hypothesis & $\begin{array}{l}\text { Knowledge about conservation sustainable } \\
\text { management issues }\end{array}$ \\
\hline $\begin{array}{l}\text { Communication } \\
\text { language and discourse }\end{array}$ & $\begin{array}{l}\text { Reinforcement and } \\
\text { reinforcement contingencies }\end{array}$ & Eco-therapy & How community people learn \\
\hline $\begin{array}{l}\text { Conservation } \\
\text { Awareness }\end{array}$ & $\begin{array}{l}\text { Psycho-environmental } \\
\text { consciousness }\end{array}$ & Bio-determination & Reelect on environmental social identity \\
\hline $\begin{array}{l}\text { Environmental identity } \\
\text { development }\end{array}$ & $\begin{array}{l}\text { Environmental conservation } \\
\text { goals }\end{array}$ & $\begin{array}{l}\text { Healing or restorative effects of } \\
\text { nature conservation and other } \\
\text { species }\end{array}$ & Perceptions of conservation risk \\
\hline Community attitudes & Environmental Promptness & $\begin{array}{l}\text { Preferences for environmental } \\
\text { conservation }\end{array}$ & Procedural conservation knowledge \\
\hline $\begin{array}{l}\text { Person-in-environment } \\
\text { and emotions }\end{array}$ & Theory of planned behavior & $\begin{array}{l}\text { Gene-bank, Zoos, Botanical } \\
\text { garden, eco-park, and managed } \\
\text { wildlife- ex-situ experiences }\end{array}$ & $\begin{array}{l}\text { Effectiveness of differing psychological } \\
\text { communication styles (fear, emotive anf } \\
\text { factual-based) }\end{array}$ \\
\hline $\begin{array}{l}\text { Environment } \\
\text { Identity }\end{array}$ & Affiliation with nature & Plant-animal-place behavior & Environmentally-identative behavior \\
\hline
\end{tabular}




\begin{tabular}{|c|c|c|c|}
\hline $\begin{array}{l}\text { Community norms and } \\
\text { cultural influence }\end{array}$ & Foot-in-the-door technique & Eco-tourism & $\begin{array}{l}\text { Learning environmental conservation } \\
\text { (behavior settings) }\end{array}$ \\
\hline Recognition & Cognitive Theory & Cognitive behavior & $\begin{array}{l}\text { Actual behavior whether peripheral or } \\
\text { central route processing }\end{array}$ \\
\hline $\begin{array}{l}\text { Moral responsiveness, } \\
\text { functioning and } \\
\text { spirituality }\end{array}$ & Respondents' Feedback & $\begin{array}{l}\text { Health and socail effects of } \\
\text { companion wildlife }\end{array}$ & Biases in cognitive information processing \\
\hline $\begin{array}{l}\text { Perceived conservation } \\
\text { behavioral control }\end{array}$ & $\begin{array}{l}\text { Community-based social } \\
\text { conserving \& identifying } \\
\text { barriers }\end{array}$ & $\begin{array}{l}\text { Managing } \\
\text { conflict }\end{array}$ & $\begin{array}{l}\text { Evaluation of environmental conservation } \\
\text { education programs }\end{array}$ \\
\hline
\end{tabular}

The Ministry of Environment, Forests and Climate Change (MoEFCC), Government of People's Republic of Bangladesh leads the environmental attitudes for integration and development of National Park Biodiversity including relevant psychological instruments, ministry or department and conservation related gaps through build up nature-loving school, media exposure, ethical awareness and effective application of modern cognitive science. Nature conservation related instruments and gap analysis discussed in details including awareness options, integration, consciousness and combination of conservation psychology for Lawachara National Park Biodiversity Management. The study also suggests that the integration of natural and social sciences in the form of two-dimensional (horizontal and vertical) gap analysis is an efficient tool (Angelstam et al., 2003) for the implementation of biodiversity conservation instruments. From these instruments, the researchers can identify easily the psychological factors. Environmental conservation psychology connects with environment, society, human behavior, human-biodiversity interaction, national agriculture and ecological status. However, these factors connected with different instruments, which are listed above mentioned table. Environmental conservation psychology is the scientific study of the reciprocal relationships between humans and the rest of nature, with a particular focus on how to encourage conservation of the natural world. It is an applied field that uses psychological principles, theories and methods to understand and solve issues related to human aspects of conservation. It has a strong mission focus in that it is motivated by the need to encourage people to take care of the natural world (Pearson, 2013). These mentioned psychological instruments like attitudes, awareness, ethical knowledge, and socio-culture can promote to reduce the illicit-felling, encroaching, illegal logging, poaching and wildlife conflict.

\section{Discussion}

The discussions on analysis of research findings on environmental psychology instruments, along with the assessment of stakeholders evaluate the biodiversity conservation at Lawachara National Park in Bangladesh. Result of this study clearly demonstrates that 'In-situ' environmental conservation psychology instrument is more suitable than participation and collaboration instruments for biodiversity conservation. Limited comparison of community settlement and place attachment instruments suitably has been undertaken and conclusions differ. In this study, the promoting of psychological instruments for National Parks and applications of environmental awareness were analyzed as criteria for suitable biodiversity conservation. The three mentioned environmental conservation instruments analyzed had different effects on National Park Biodiversity Management, awareness and collaboration in Bangladesh - as a signatory State Party of CBD's objectives requirements. The findings on the existing psychology instruments are inadequate in connection with national and global perspectives, where there are some gaps, like lack of environmental education, dynamic collaboration, stakeholder participation, establishment of psychological conservation supports in the society. However, national parks are instrumental in supporting biodiversity conservation as well as providing many benefits to the society (Miah et al, 2017).

\subsection{Stakeholder Involvement}

The study contains different sections model development of stakeholders' engagement, criteria for improvement, attitudes and enhancement for positive conservation psychology and Sustainability, Priority-based model for community-based conservation that creates awareness among stakeholders are incorporated and well represented with psychological instruments in Figure 7. Stakeholder engagement theory is associated with the person-environment assessment using stakeholder analysis. The outcomes of the study on stakeholders' roles in national park's biodiversity management that the positive attitude instrument process would be effective when 
stakeholder clearly understand the goals of their involvement, their responsibility in the course of action and the issues implicated (Treves et al., 2005). The study integrates participation, collaboration from stakeholders like park manager, biological diversity specialists, ecological specialists, wildlife managers, academicians and relevant bodies. The study signifies the uniqueness of the tools used to enhance national park conservation professionals on the national biodiversity strategic action plan through existing psychological instruments. It is very imperative to engage with key stakeholders to converse and recognize challenges and possible solutions related national park biodiversity losses and associated ecosystem service declines (Rose et al., 2014). Participatory dialogue comprehensive of multiple stakeholders is crucial to appreciate and discourse different perspectives and needs (Martin, et al., 2000), and considered many benefits to conservation instrument implementations (e.g. BCHM, greater legitimacy decisions, higher-quality decisions, increased compliance) (Menzel and Teng, 2009). This type of discussion can also familiarize stakeholders to potential participation concepts, based on information from other areas. Finally, the study advocates a new collaborative approach to drive the stakeholders' potentiality to further incorporate the conservation awareness integrating next generations' biodiversity conservation perspectives. The study suggested that engagement of stakeholders enhances the conserving of national park biodiversity with required promoting psychological instruments.

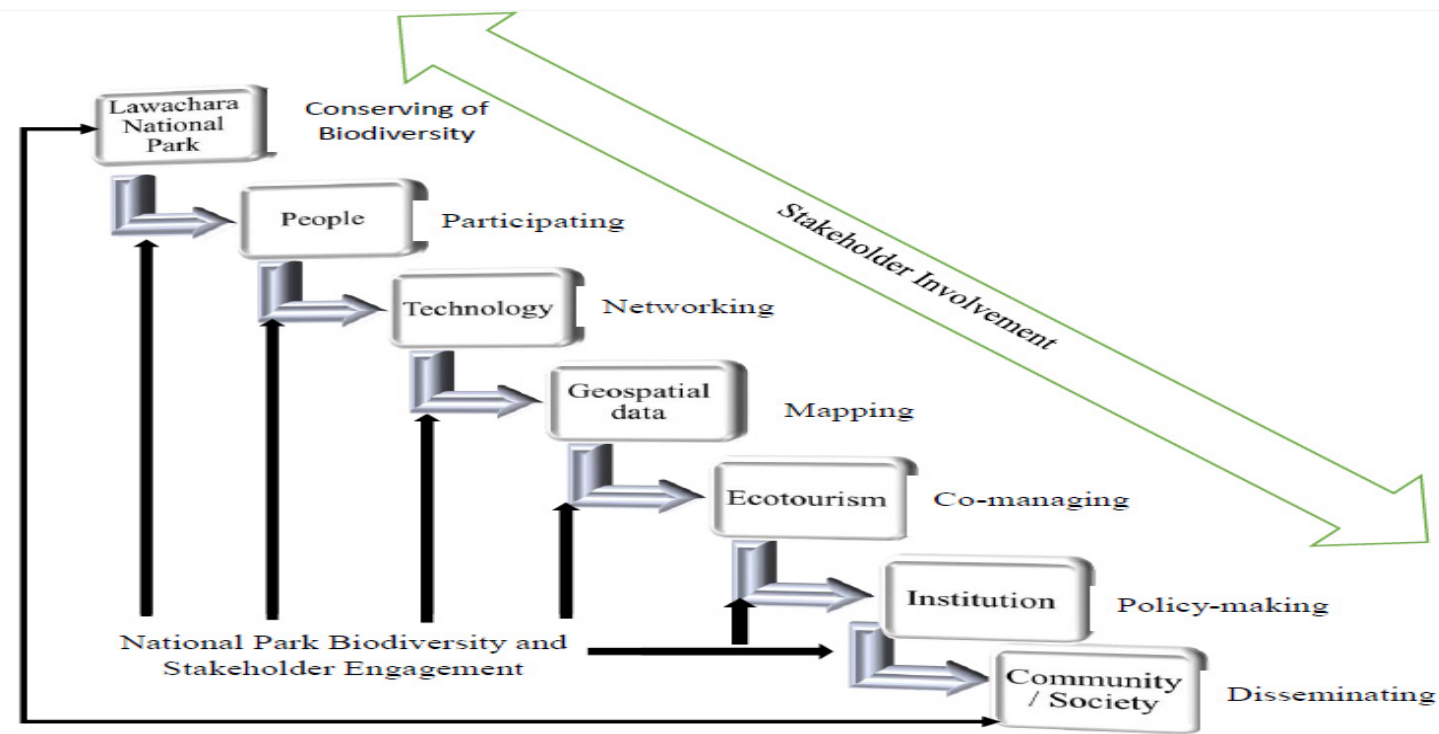

Figure 7. Stakeholder engagement on National Park Biodiversity

\subsection{Human Biodiversity Psychological Interactions}

Today more than $75 \%$ of the terrestrial surface is impacted by human (Ellis et al., 2010). Human-biodiversity interactions enhance to counteract possible outcomes (Gardner et al., 2009). This is the intangible outline of human - biodiversity and national park connections and possible outcomes for strength and safety (Barber, 2004), perception of biodiversity, connection with conservation education and pro-biodiversity behaviour (Pett et al, 2016). From this framework, conserving of biodiversity reduced anthropocentric pressure from adjacent areas' inhabitants, particularly dependency of human beings towards national parks. This is shown in Figure 8 that the question symbols signify less well-understood associations. 


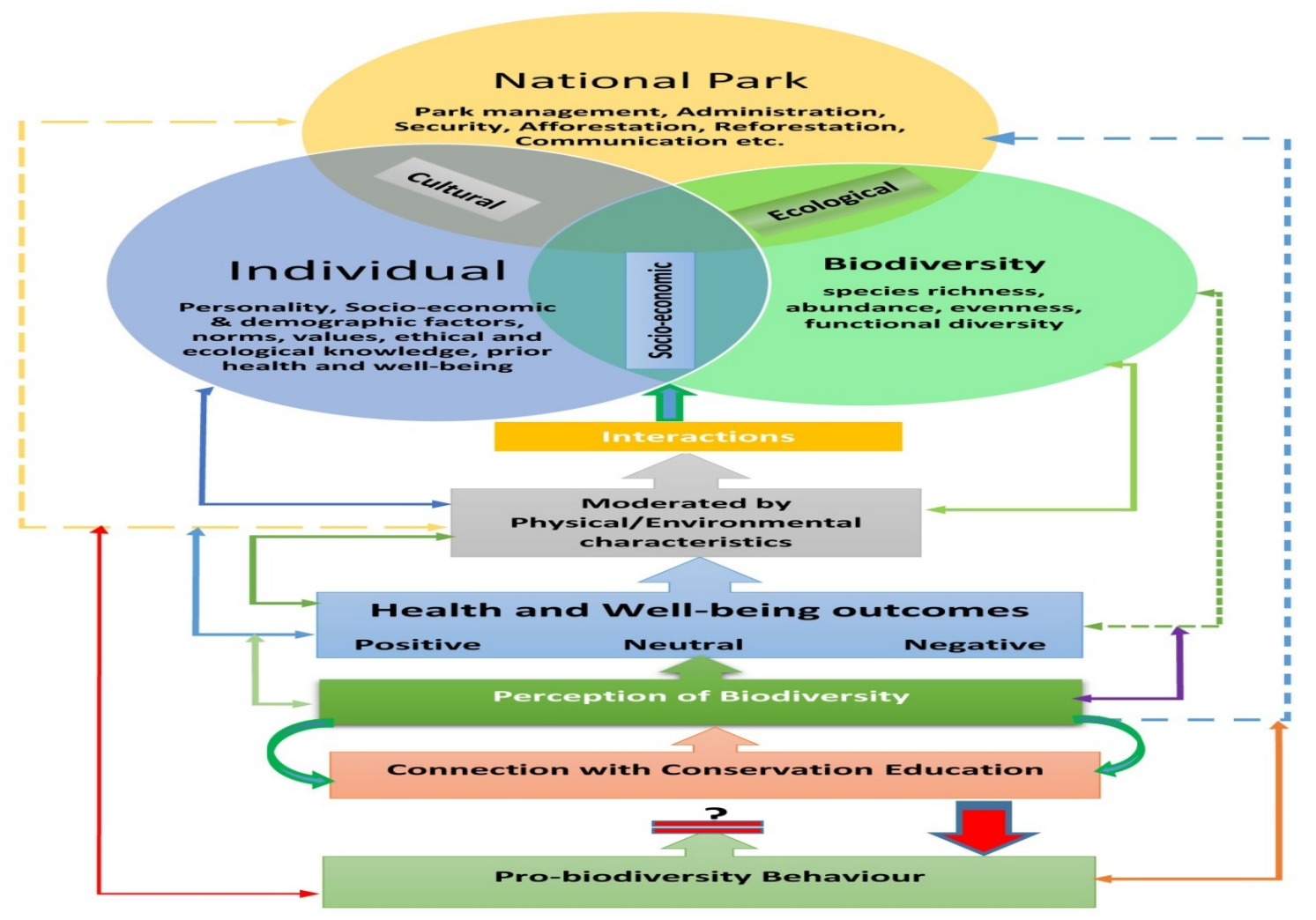

Figure 8. Conceptual Framework of human—biodiversity and national park interactions

The spotted lines characterize response from results back to biodiversity or the specific object. Meanwhile, human-biodiversity reflection connects with local and indigenous people for environmental education to manage national park biological diversity conservation, especially on health and well-being outcomes including the ratio of total landscape area, national park area and population density.

\subsection{Tourism and Psychological Reflection}

Tourism is a growing services market (UNEP, 2004). It is connected with nature-based place attachment. Visitors can enhance the ornamentation of National Park biodiversity conservation depending on access, attitude, behaviour and movement. Visitors' numbers in most national park areas around the world are increasing (Balmford et al., 2002; Holden, 2016; UNTWO, 2017). There are two types of visitors, such as (i) national visitors, and (ii) foreigner visitors in Lawachara National Park (Figure 9). In 2011, there were 773 foreigner visitors out of 648,13 to Lawachara National Park in Bangladesh (IPAC, 2012), meanwhile 305,31 foreigner visitors out of 42,810 of Malaysia in the same year (SF, 2012). From the findings, political instability and lack of security are the root causes of less foreigner visitors in Bangladesh. It mentioned that the entry fee at Bako National Park is RM 20/-, where RM 1/- (equals BDT 20) the entry fee at Lawachara National Park. For attracting more visitors and mitigating impacts need conservation reserve as a means of value adding that can alter visitors experiences (Zhang et al., 2009). These experiences are:

(i) natural scenic view,

(ii) modern ecotourism services,

(iii) eco-guide cooperation,

(iv) national park administrative collaboration,

(v) local community's perception,

(vi) media exposure related national park - a historical place identity, and

(vii) effective communication and security services.

For the purpose of national park biodiversity conservation and recreation, uncertainties surround whether 
negative impacts occur. The reported trend in recreational activity requires debate; instruments direction and target areas need national park area management effectiveness evaluation to assess conservation implications (Newsome and Hughes, 2018) in connection with ecotourism activities at Lawachara National Park.

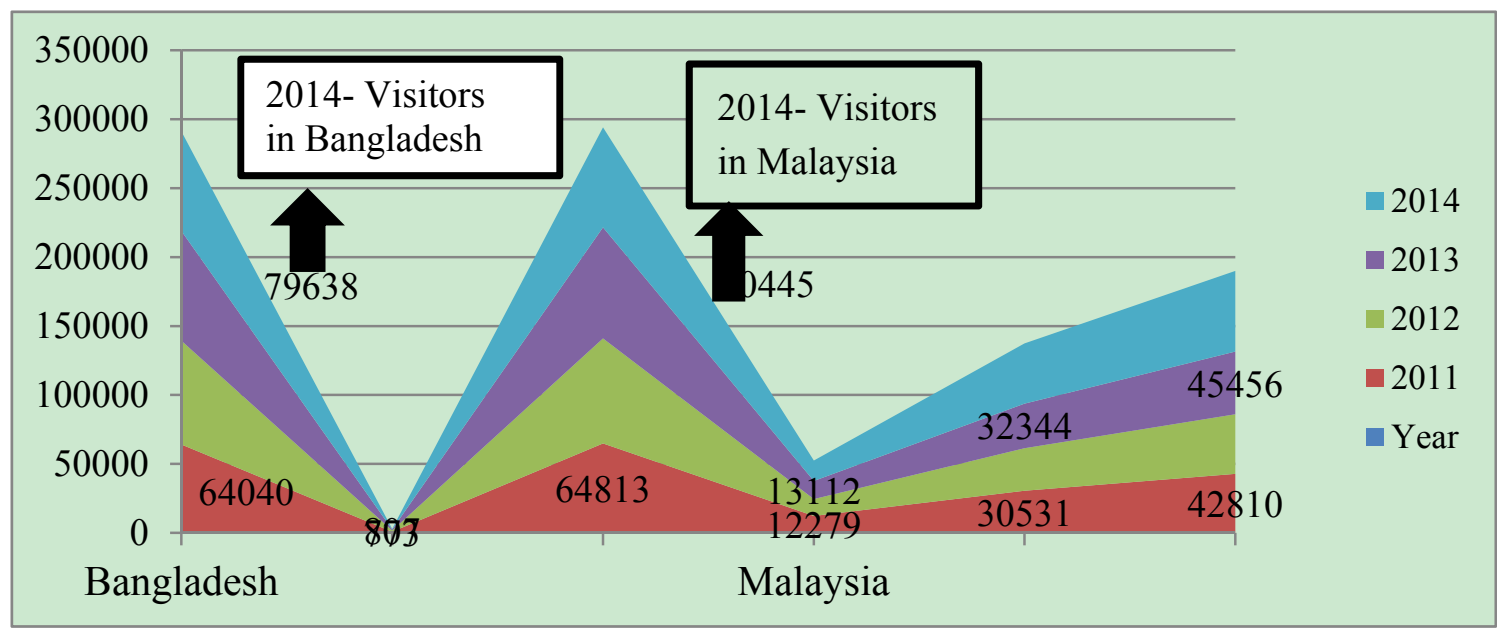

Figure 9. National Park visitors between Bangladesh and Sarawak, Malaysia

Visitors seek outdoor recreation performs are increasing in national park (O'Neil et al.2010, Ramkissoon et al., 2011\& 2013; Tonge et al., 2011).

\subsection{Environmental Conservation Education}

Environmental conservation education represents to improve awareness and concern among the global population for the environmental conservation while enhancing growth of knowledge, trained-up, skills, attitudes, norms, motivations, ethic and commitment to search solutions for environmental conservation issues either individual or integrated group action (UNESCO-UNEP, 1976). According to worldwide application, the pertinent context and setting for issues illustrated by environmental conservation education is broad, and program design range from free-choice conservation-science-learning to more structured initiatives that take place within affiliations (Dierking and Falk, 1994; Falk, 2005; Salata and Ostergren, 2010). As an integrated part of environmental conservation education initiatives, social science frameworks can contribute to a better understanding of target audience cognitions including norms, values, attitudes, perceptions on the existing knowledge, and barriers and perceived ability to take action to solve environmental issues (Teel and Manfredo, 2010; Thomas et al., 2014; Hungerford and Volk, 1990). Environmental conservation education indicates to influence awareness, ecological sensitivity, community engagement and pro-environmental behaviors through a foundation of knowledge, values and attitudes. Current research in this field links to improve program development through better understanding target audience characteristics and evaluating the effectiveness of environmental conservation education and outreach campaign (Heimlich, 2010; Hungerford and Volk, 1990; UNESCO UNEP, 1976; Betiang, 2010; Kuhar et al., 2010; McDuff and Jacobson, 2000; Thomas et al., 2014). Local community's environmental education is essential for protection of National Park biodiversity. Because the quick losses of biological diversity throughout the previous decades, which managed to sprouting trepidations at local, divisional, regional and national as well as global stages (Solh et al., 2003). Natural heritage such as Lawachara National Park (LNP) is under threat with high tendency to losses of biodiversity (CNRS, 2000). Local community and indigenous people over-exploit national park biodiversity but none can effectively conserve due to lack of systematically dynamic psychological tools. Encouraging field-based-student-scientist commitments to protect local biodiversity is an imperative goal of psychological education (Jacobson, 1987) for sustainable development in Bangladesh and elsewhere. The task attempts to overlook the EE to create knowledge, awareness and necessary skills to solve the key aspects with references to the local context, which reform the policy towards conserving biodiversity at LNP in Moulvibazar district. The study showed that almost $65 \%$ of the respondents opined their opinions for augmenting EE with systematic curriculum development, scientific action-oriented programmes, and empirical education, enthusiastic to digital conservation and visualization, ecological field exposures, sectoral integration, and academia effective trainings. The study signifies that the frequencies of national environmental conservation related legislations maximized for the period of 2010 to 2016, which are placing upon the EE. The research fostered a comprehensive framework to 
explore the efficacy of EE (Solh et al., 2003) on government and non-governmental partnership and its effectiveness. This is indeed a positive sign on key stakeholders' awareness upon the sustainable biodiversity conservation and EE for Bangladesh towards achieving Aichi Biodiversity Targets beyond globally environmental networks.

Overall, the study emphasizes the dynamic policy-making decisions on sustainable conservation at NPs further environmental motivation at local, national and global collaborative approaches should incorporate development with social, political, economic, institutional and administrative purviews. The literacy rate of Kamalaganj is $48.6 \%$ to compare with Moulvibazar Sadar (54.9\%) in consciousness of environmental education at Lawachara National Park (BBS, 2013). Conservation psychologists can be trained-up the national park staff to use the intriguing details of how wildlife and parks functioned to better inform visitors in connection with local communities about the need for biodiversity conservation (Cranston, 2016). The idea of an important piece of biodiversity conservation was reinforced by a theory popularized in the 1980's known as the knowledge-deficit model.

\subsection{Psychological Tools Integration for Conserving of Biodiversity}

The field of conservation psychology offers a meta-theoretical framework for attitudes and attachment in the environmental conservation phenomena. This approach is applied to specific policy problems, focusing on those problems contexts rather than seeking psychological solutions (Ascher et al., 2010; Clark, 2011; Chamberlain et al., 2012; Clark et al., 2008; Rutherford et al., 2009). Bangladesh is a developing country, consists of different sectors and departments, like Bangladesh Forest department, Department of Environment, Department of Agriculture and social welfare. Each sector has individual policy, viz. forest policy, agriculture policy, environmental policy, and land policy etc., in connection with diversified roles, for examples: The national forest policy enhances the implementation of sustainable forest management and supporting national forest programs, as well as the environment remains one of the most important sectors influencing the state of environmental resources. For these purposes, psychological factors enhance conserving of national park biodiversity through attitude, awareness, perception, opinion, collaboration, integration and brainstorming discussion using the rules and regulations of forest and environment. There is a shared important link among these sectors for sustainable development, social and economic reforms and their integrations for specific policy areas (Owens and Hope, 1989).

From the point of research, biodiversity policy relates with public policy, which is related to National Biodiversity Strategy and Action Plan (NBSAP). Article 6 of the CBD requires each State Party to develop a NBSAP for implementation of the Convention's objectives, to integrate the plan's objectives into sectoral policies and to report to other Parties about related positive and negative efforts, successes and failures (CBD, 1992). Government of Bangladesh adopted a NBSAP to halt the loss of biodiversity in Bangladesh and to reconcile protection with the interests of users (DoE, 2016). Recent research informs environmental conservation law through determining how to create socially appropriate and effective regulatory structures, legal frameworks and standards for the protection and optimum use with sustainable manners and attitudes of natural environment and feasible mechanisms for the enforcement of those standards (Boyd, 2011; Gillespie, 2012; Owley,2015; Curran, 2015; Van Hoorick, 2014; Walter et al., 2000; White, 2011). Environmental conservation law involves rules of behavior, interaction, use and stewardship of the environmental conservation mentioning the scale at which conservation can occur and the actors who have a formal role and responsibility in management. The study argued that broad interdisciplinary science and academia practice partnership are central integration to a sustainable development of digital conservation (Arts et al., 2015) in connection with cognitive science and human-computer interaction towards National Park Management. Environmental conservation attitude theories represented in a rational choice perspective must be situated within the realm of conventionality but the conventional social influences are not effective in the ecological domain (Hornik et al., 1995; Schultz et al., 1995).

\subsection{Challenges for Dynamic Psychological Conservation Efforts}

Bangladesh faces a number of challenges for empirical dynamic psychological factors. It is a real-world challenge to implement the human-centred national biodiversity strategy and action plan (NBSAP) tools with Aichi Biodiversity Targets (ABT) design for national park visitors that considered what visitors needed to strengthen their relationships and behaviors with park's biodiversity. On the other hand, the conservation psychology research has been challenges of nomenclature, achieving objectives and repeatable findings, research goals and the facts that some study mean on underlying assumptions about human-perception, which is not completely tacit. It is tough for the field study to fit into institutional structures. Besides, Bangladesh as a developing country, 
environmental psychology has not received nearly enough supports to be considered an interdisciplinary field with psychology. Environmental conservation psychology integrates a somewhat be wildering assortment of incongruent approaches, intangible orientation and interpretation, which is making its difficulties to allocate with any degree of sensitivity, just what the psychological domain is all about and what might it subsidizes to the construction of society and clarifying conservation history of community's mind setting-up surrounding the national park. Only a single body cannot resolve global environmental conservation challenges, whether environmental conservation psychology assists to enhance the combined aspect of such action.

Mainly, it is alarming that matters such as Central Government Psychological instruments can be effectively executed at the local government and department levels in Bangladesh; it would to need sectorial/departmental policies integration, where lack of communication strategies including decision-making and psychological factors. According to Global Risks Report (2016), Malaysia is more risks country on cyber-attacks (score 38.6) than that of Bangladesh (score 7.1), but Bangladesh is more vulnerable on natural catastrophes (score 17.9) than that of Malaysia (score 11.9). From environmental performance index (EPI) report stated that biodiversity scoring of Malaysia is more (93.37\%) than that of Bangladesh (39.68\%) (EPI, 2015). The study reflects that environmental psychological performance of Malaysia is higher than that of Bangladesh. However, a psychological instrument in the context of biodiversity conservation is an integration of environmental tools that has advanced to inspiration the magnitude and worth of conservation of national park biodiversity (Ring and Schroter-Schlaack, 2011a) and growth of national parks options in government and non-governmental sectors. Therefore, several causes have been given to justify the cost effectiveness of policy integration for biodiversity conservation. The World Competitiveness Ranking of Malaysia is 24 but Bangladesh has no rank as a whole (WCR, 2017). The study compared with World Competitiveness Ranking 2017, which reflects on green economy in connection with sustainable biodiversity conservation towards national parks. The research indicates that global psychological competiveness is changeable on the priority of geopolitics, location, communication and economic performance. Moreover, environmental conservation psychology is necessary with geographic location for sustainable biodiversity conservation on the requirements of Aichi Biodiversity Targets 2020 and Sustainable Development Goals 2030 .

\subsection{Economic Instruments for Changing Behaviour}

Community Behaviour change is the effective instrument surrounding the Lawachara National Park (LNP) for conserving of biodiversity. LNP Manager may interest in using fiscal instruments to change the behaviour of economic actors with respect to maintaining the National Park area and conserving biodiversity. There are some fiscal instruments to assist for LNP biodiversity conservation, such as: (i) Special Area visit tax inside the park, (ii) Biodiversity Green Fund, (iii) Biodiversity Tax deduction scheme, (iv) Develop NP revenue stamp/ postal card, (v) Biodiversity incentive through cultural programme, (vi) Biodiversity Tax for those companies who received environmental clearance, (vii) Using a NP lottery to help biodiversity fund, (viii) Tourism company tax fund, (ix) Voluntary Fund for biodiversity, (x) NP Boarding/Lodging rent tax for biodiversity fund, (xi) Green Banking Fund, (xii) Tax for LNP Vehicle Road and Railway Route permits, (xiii) Biodiversity donation for spot picnic programme. The love community people have for environmental conservation is dynamic. Moreover, protection of the environmental conservation should take precedence over national economic growth through changing behaviors.

\subsection{Ethical Knowledge Instruments for Biodiversity Conservation}

Bio-religious knowledge implies with biodiversity and religion of local community in pivotal role of decision-making. Biodiversity is a major component of ecological integrity assessment (Andreasen et al., 2001; Parrish et al., 2003; Willamette Partnership, 2011; Unnasch et al., 2009; Faber-Langendoen et al., 2012a and b; NatureSurve, 2012; Vickerman and Kagan, 2014). Biodiversity conservation through local communities is an ongoing challenge, which is to develop the environmental religious knowledge that can be used for effective conservation and management. Biodiversity and community interlinked with mother tree, species composition, diversity, habitat quality, ecosystem structure, composition and function. From the study of Lawachara National Park (LNP), the mother tree reduced continues and affected on National Park Biodiversity. For religious consciousness of the value of biodiversity conservation, the local and indigenous community conservation integrity is necessary. LNP is located Kamalganj sub-district, where the inhabitants are performed as Muslim, Hindus, Buddhist and Christian. The religious leaders of these religions can contribute the Community Conservation Integrity (CCI) for biodiversity on Lawachara National Park. This awareness dissemination will reflect positive psychology with their beliefs, ethics and morals. For this purpose, Bio-Religious Knowledge Management Centre can be established at Mosque, Church, Temple, and Pagoda for conservation integrity. This integrity indicates the cultural value towards biodiversity, which is evident across the globe. Specific species of 
biodiversity are often central to our cultural identity (Clark \& Lovell, 2014).

\subsection{Stimulating Tools Development for Conserving of Biodiversity}

Environmental psychology stimulates the park manager, visitors, local community leaders and co-management team in terms of achieving desired behavioural responses for the protection of National Park (NP) Biodiversity. From the field survey, about $65 \%$ respondents opined for augmenting of environmental education. However, environmental psychology is the knowledge of connections between these respondents and national park's physical settings (Gifford, 2007a). In these connections, these stakeholders recover their national park environmental conservations, their behavior and experiences are improved by their national park's biodiversity protection. It includes theory, research, practice, performance or communication connected with stimulating the built environment more humane and improving human relations with the national park biodiversity habitation (Gifford et al., 2011). Therefore, environmental psychology is the key component of both human and national park welfare through collaborative management that promotes desired emotional or behavioral outcomes (Donovan and Rossiter, 1982). Environmental psychologists investigate the impacts of spatial environments on behavior. Emotional responses to national park conservational stimuli fall into three dimensions, (i) pleasure, (ii) arousal, and (iii) dominance (Donovan and Rossiter, 1982) as shown in Figure 10. The stakeholder's emotional state is thought to facilitate the behavioural responses either approach or avoidance behaviour towards the LNP Biodiversity protection. Decision-maker, Park Manager, Co-management team leader and conservation specialist can use perceptions from environmental psychology to conserve biodiversity that improve preferred emotional positive effects. For example, ornamental and flowering species for natural scenic view, music for biodiversity protection, watching feeding habit of wildlife and jumping of monkeys, which attract to the visitors and increase revisit of them to national park. Visitors' contributions enhance national park's biodiversity conservation, which interlinked with cognitive, emotional and psychological responses. For instance, human interactions with national park and the role of psychology contribute in climate change (Gifford, 2008a) to overcoming sustainability problems in the national and global ecosystems ( Gifford, 2007b; Nickerson, 2003).

\section{Processing}

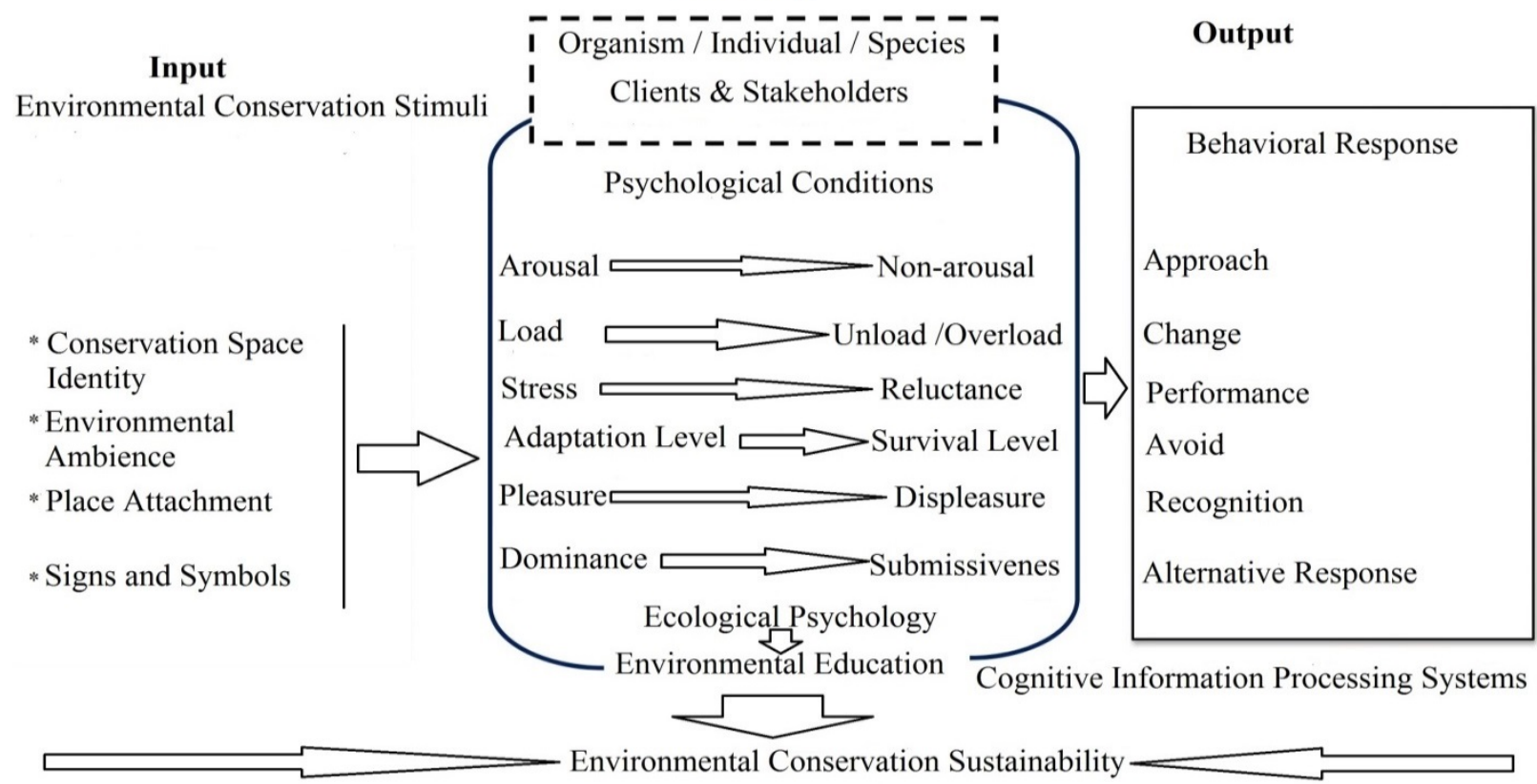

Figure 10. General model of environmental psychology for stimulating conservation of biodiversity

Prior research has often emphasized individual values, attitudes, beliefs, norms and behaviors and employed a diversity of methods ranging from quantitative surveys to more qualitative techniques such as interviews, focus groups, field observations (Bennett et al., 2017). Contributions to conservation have included anticipating people's responses to environmental conservation issues and interventions, determining more socially acceptable management actions, informing communication and other attitude behaviour changes strategies, and 
understanding the basis for and address social conflict among different community segments and users groups (Bennett et al., 2017). Promising new directions in this area call for greater attention to emotions and broader cultural and societal-levels influences on human behavior (Manfredo et al., 2014a, 2014b).

\subsection{Environmental Conservation Behavior and Research Domain}

Environmental conservation sustainability is the urgent need to reduce the negative impact of humans and promptly necessary to appreciate environmental conservation friendly behavior. This conservation behavior interlinks with environmental conservation research design, which as shown in Figure 11.

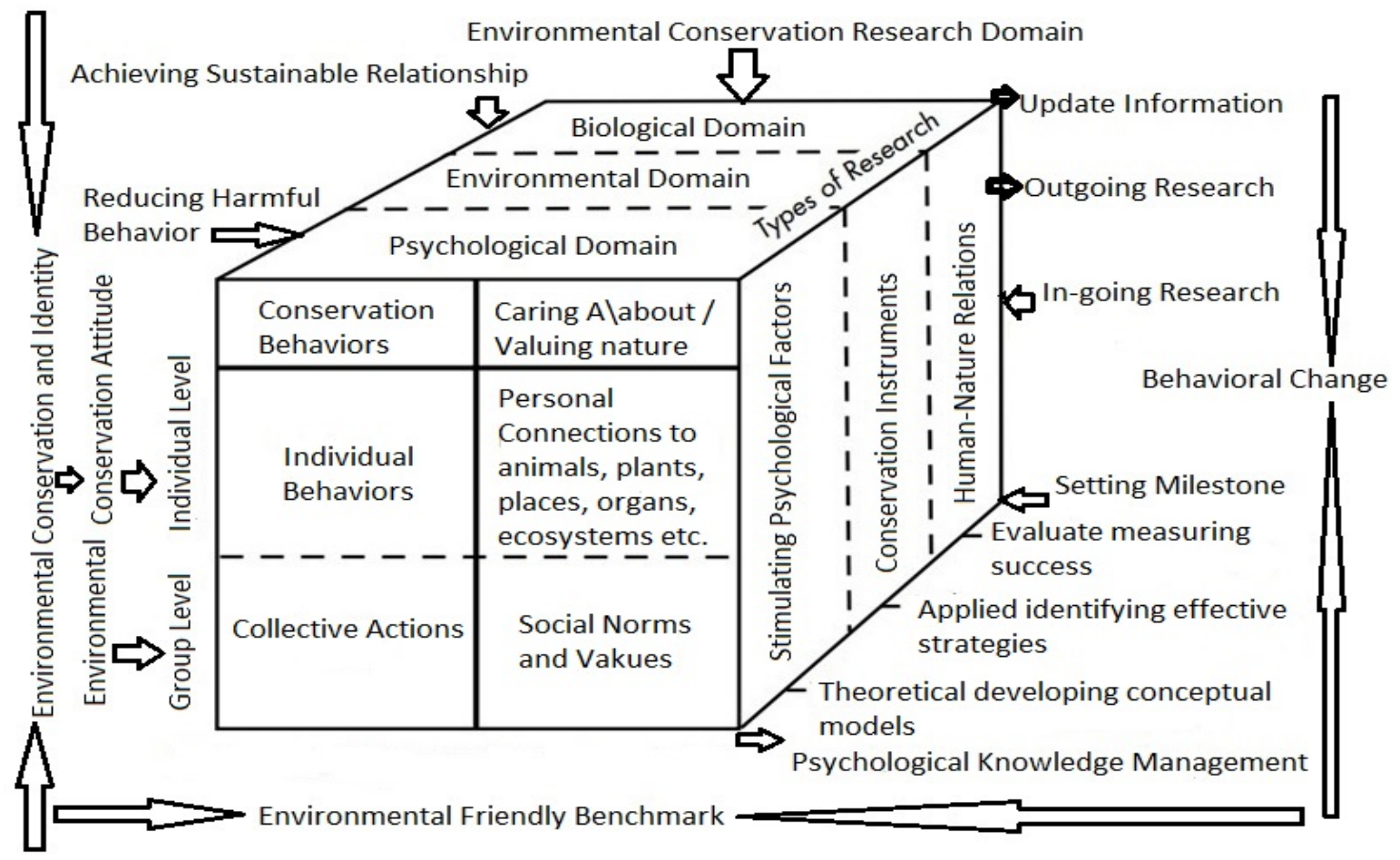

Figure 11. Enhancing positive conservation psychological research design

Environmental conservation psychology takes into account one's social and environmental surroundings that played an important role in applied conservation social science research (Clayton et al., 2013; Clayton and Myers, 2015; Gifford, 2014; Manfredo, 2008; Saunders, 2003; Vaske and Manfredo, 2012). The values and contributions, the environmental psychology can be effective instrumental to biodiversity conservation in 5 categories (Bennett et al., 2017), such as: (i) improve management practices and governance processes, (ii) enable better conservation designs and models, (iii) justify conservation actions, (iv) help to achieve ecological outcomes, and (v) facilitate more socially equitable processes and outcomes.

The ongoing monitoring and evaluation of environmental conservation considerations is key to improving the effectiveness of management practices, quality and legitimacy of conservation processes (Borrini-Feyerabend et al., 2013; Hockings et al., 2006; Lockwood, 2010; Pomeroy et al., 2004). From this study a structural environmental conservation model connecting with awareness, perception, emotions, opinions, personal-philosophical values, perceived control and conservation behavior was proposed and identified. The highest impact on environmental conservation behavior identified from personal-philosophical values and conservation emotions. No effects on environmental conservation behavior representing from factual knowledge were observed to compare with traditional culture.

\subsection{Psychological Tools for Biodiversity Conservation}

Environmental conservation psychological opportunities enhanced for collaboration with the group of respected environmental psychologists from the field of environmental conservation science and psychology to the national park for a brainstorming session in the form of the developing and promoting caring attitudes towards LNP planning and designing. During the paying attention, environmental psychologists, developmental psychologists, environmental educators, early childhood development learning specialists, collaborative 
management team, biodiversity specialists, informal learning specialists, tea-garden managers and exhibit developers worked with national park staff in small sub-groups on various issues and questions related to fostering a caring ethnic in a visitors' park environment. The group discussed in the form of problem-advocate panel, national park manager would explain a certain goal, they wish to accomplish and the panel members and co-management team would share insights about how to strategically accomplish those goals from the perspective of their areas of expertise. The discussion session compiled the planning principles and related ideas regarding the applications of psychological theory in developing and promoting a caring attitude towards the national park biodiversity conservation.

The fundamental success of environmental conservation psychology is based on whether its research resulted in conservation programs and applications that represented a difference with respect to environmental conservation sustainability. The environmental research need to able to identify the effectiveness of the conservation motivational programs in terms of their effects on behavior formation and /or changing behavior with using scientific tools developed by environmental conservation psychologists (Saunders, 2003). This research activity relates with natural scientists to indicate that the conservation behavior changes have positive impacts on high-priority environmental conservation functions and features.

\subsection{Psychological Gaps for Conserving of Biodiversity}

Dynamic people are paying attention to the real gap of environmental conservation psychology that seemed to separate conservation work and the social sciences outside of the national park. Meanwhile, there was little published research about psychological approaches to biodiversity conservation sustainability at the stipulated time. Along the way, the need for additional basic researcher became clear. Besides, environmental conservation psychology theme deals with the behavioral attitude issue, indicating the gap between environmental conservation attitude and biodiversity conservational behavior remains a challenge (Kaiser et al., 1999; Smythe $\&$ Brook, 1980).

\subsection{Psycho-biological Research Implications}

In Bangladesh, the concept of environmental conservation psychology has become to a greater extent recognized as a crucial element of the decision-making process at all levels. Problems in expanding and executing the environmental conservation psychology in Bangladesh curtail from numerous causes. One of the causes was an unstable political circumstance, which appeared when the research was conducted. Considerably, one vital reason that generates this process more complicated is the conventional decision-making procedure by the authorities, which always overlooks the public. Besides, the national constitution, laws, orders, rules and regulations must be reformed to ensure that national park biodiversity management is flaxen, clear and visible, and supports a public involvement strategy within the Government of Bangladesh Administration. Laws reform initiatives, above all the outlining process, should apply a participatory appraisal to national park biodiversity management. The reforming process should allow all stakeholders, specifically the public, academics, researchers, environmental psychologists, relevant government bureaus, NGOs, co-management team and local inhabitants be involved in making their opinions recognized during the writing of these laws on environmental conservation so as to achieve their goals. To achieve an effective environmental conservation psychology, a comfortable thinking, accepting and knowledge of national park biodiversity are desired. Practical training and guidance, biodiversity conservation- related workshops and career paths should be conducted for the organizational concerned, co-management team, local communities, officials and the public's motivational knowledge.

\subsection{Psycho-biological Research Limitations}

To date applications of environmental conservation psychology have been limited to evaluation of a single conservation variable measure of environmental conservation impacts, such as loss of biodiversity, changes in population affluence and misuse technology. This research limits to assess the effectiveness of environmental conservation psychology for biodiversity conservation at Lawachara National Park in Bangladesh by investigative the process of psychological instruments directly. The research results highlighted a challenging study of the psychological conservation instruments as they were based on environmental conservation at Lawachara National Park - a case study in Bangladesh connecting with Aichi Biodiversity Targets. The strength of the research relied on its constrained design. While the respondents were chosen using snowball sampling to make discretely them more self-determining and less bias. The national park case study approach and the small sample size of respondents limit the applicability of the psychological research outside the context within which it was conducted. 


\section{Conclusion}

In concluding the study, environmental psychology can be valued to biodiversity conservation for state-of-the-art, linking expressive, indicative, disruptive, instinctive, multiplicative and influential details towards its niche area adjacent national park. This study and relevant materials provides a succinct yet comprehensive reference for park managers, researchers, conservationists, psychologists, scientists, biodiversity specialists and practitioners. This research can stimulate enable to develop the biodiversity conservation policies, engagements and outcomes that are further dynamic, legitimate, effective, robust and significant for the present and rationalized generations. Based on the psychological instruments, Lawachara National Park (LNP) is not well developed on the priority of national park stakeholder's involvement, participation and visitor's satisfaction with community's positive environmental psychology. However, the predisposing conditions of this LNP also have the psychological negative effects on poaching, hunting, illegal logging and encroaching, local corruption and political bias along with weak collaboration and institutional less supports to the losses of biodiversity. Moreover, local people's conservation behavior is necessary as an urgent basis with dynamic stakeholders and psychological niche area. The study advocates future research trajectories of a new kind collaborative alternative approach to drive the methodological agenda and recommendations on how to further incorporates the stimulating environmental psychology for motivating biodiversity conservation.

\section{Competing Interests}

The authors declare no potential conflict of interests in this research work. The funders had no role in the design of the research, in data collection, analyses or final interpretation of data, in the writings of the manuscript, or in the decision to publish the findings.

\section{Acknowledgement}

The authors acknowledged the authority of Universiti of Malaysia Sarawak (UNIMAS), Malaysia for providing the Zamalah Postgraduate Scholarship for the completion of PhD Program. The authors are also grateful to the authority of the Information and Communication Technology Division, Ministry of Posts, Telecommunication and Information Technology, Government of People's Republic of Bangladesh, for financial supporting as $\mathrm{PhD}$ Fellowship during the higher study at UNIMAS, Malaysia.

\section{References}

Ajzen, I. (1985). From intentions to actions: a theory of planned behaviour. In J. Kuhl, \& J. Beckmann (Eds.), Action Control: from cognition to behavior (pp. 11-39). Berlin, Germany: Springer. https://doi.org/10.1007/978-3-642-69746-3_2

Ajzen, I. (1991). The theory of planned behavior. Organizational Behavior and Human Decision Processes, 50, 179-211. https://doi.org/10.1016/0749-5978(91)90020-T

Ali, S. A., \& Habib, M. G. (1998). Collaborative Management of Protected Areas in Bangladesh. Case Studies presented in Regional Workshop on Collaborative Management of Protected in South Asia, Kathmandu, Nepal 25 - 28 May 1998.

Andreasen, J. K., O’Neill, R. V., Noss, R., \& Slosser, N. C. (2001). Considerations for the development of a terrestrial index of ecological integrity. Ecological Indicators, 1(1), 21-35. https://doi.org/10.1016/S1470-160X(01)00007-3

Angelstam, P., Mikusinski, G., Rönnbäck, B., Anders Östman, A., Marius Lazdinis, M., Roberge, J. M., Arnberg, W., \& Olsson, J. (2003). Two-dimensional Gap Analysis: A Tool for Efficient Conservation Planning and Biodiversity Policy Implementation. Ambio, 32, 527-534. https://doi.org/10.1579/0044-7447-32.8.527

Arts, K., van der Wal, R., \& Adams, W. M. (2015). Digital technology and the conservation of nature. Ambio, 44(suppl. 4), S661-S673. https://doi.org/10.1007/s13280-015-0705-1

Ascher,W., Steelman, T., \& Healy, R. (2010). Knowledge and Environmental Policy: Re-imagining the Boundaries of Science and Politics. MIT Press, Cambridge, MA. https://doi.org/10.7551/mitpress/8398.001.0001

Axelrod, L. J., \& Lehman, D. R. (1993). Responding to environmental concern: what factors guide individual action? Journal of Environmental Psychology, 13, 149-159. https://doi.org/10.1016/S0272-4944(05)80147-1 
Balmford, A. P., Crane, A., Dobson, R., Green, E., \& Mace, G. M. (2005). The 2010 challenge: Data availability, information needs and extraterrestrial insights. Philosophical Transactions of the Royal Society B, 360, 221-22. https://doi.org/10.1098/rstb.2004.1599

Barber, C. V. (2004). Parks and people in a world of changes: Governance, participation and equity. In C. V. Barber, K. R. Miller, \& M. Boness (Eds.), Securing protected areas in the face of global change: Issues and strategies (pp. 97-136). IUCN, Gland, Switzerland and Cambridge, UK.

BBS. (2013). Moulvibazar District Statistics 2011. Bangladesh Bureau of Statistics (BBS), Statistics and Informatics Division (SID), Ministry of Planning, Government of People's Republic of Bangladesh.1-117.

Bennett, N. J. (2016). Using perceptions as evidence to improve conservation and environmental management. Conservation Biology, 30(3), 582-592. https://doi.org/10.1111/cobi.12681

Bennett, N. J., \& Dearden, P. (2014a). Why local people do not support conservation: community perceptions of marine protected area livelihood impacts, governance and management in Thailand. Marine Policy, 44, 107-116. https://doi.org/10.1016/j.marpol.2013.08.017

Bennett, N. J., \& Roth, R. (2015). The conservation social sciences: What? how? and why? Canadian Wildlife Federation and Institute for Resources, Environment and Sustainability, University of British Columbia, Vancouver.

Bennett, N. J., Roth, R., Klain, S. C., Chan, K., Christie, P., Douglas, A., ... Wyborn, C. (2017). Conservation social science: Understanding and integrating human dimensions to improve conservation. Biological Conservation, 205, 93-108. https://doi.org/10.1016/j.biocon.2016.10.006

Betiang, L. (2010). Theatre of rural empowerment: The example of living earth Nigeria Foundation's community theatre initiative in Cross River State, Nigeria. Res. Drama Educ. Journal Applied Theatre Perform, 15, 5978. https://doi.org/10.1080/13569780903481037

Borrini-Feyerabend, G., Dudley, N., Jaeger, T., Lassen, B., Pathak Broome, N., Philips, A., \& Sandwith, T. (2013). Governance of Protected Areas: From Understanding to Action. IUCN, Gland, Switzerland.

Boyd, D. R. (2011). Unnatural Law: Rethinking Canadian Environmental Law and Policy. UBC Press, Vancouver.

CBD (Convention on Biological Diversity). (2016). Application of GIS to biodiversity monitoring [Author: B.B. Salem]. Retrieved July 10, 2017, from www.cbd.int/doc/articles/2003/A-00152.pdf

CBD. (1992). Articles, Convention on Biological Diversity, United Nations, 2-30. Retrieved July 15, 2016, from https://www.cbd.int/convention/text/default.shtml

Ceballos, G., Ehrlich, P. R., Barnosky, A. D., Garcia, A., Pringle, R. M., \& Palmer, T. M. (2015). Accelerated modern human-induced species losses: Entering the six mass extinction. Science Advance, 1. E1400253. https://doi.org/10.1080/13569780903481037

Chamberlain, E. C., Rutherford, M. B., \& Gibeau, M. L. (2012). Human perspectives and conservation of grizzly bears in Banff National Park, Canada. Conservation Biology, 26, 420-431. https://doi.org/10.1111/j.1523-1739.2012.01856.x

Cheung, L. T. O, \& Hui, D. L. H. (2018). Influence of Residents' place attachment on heritage forest conservation awareness in a peri-urban area of Guangzhou, China. Urban Forestry \& Urban Greening, 33, 37-45. https://doi.org/10.1016/j.ufug.2018.05.004

Chevalier, J. M., \& Buckles, D. J. (2013). A handbook for participatory action research, monitoring and evaluation. SAS2, Ottawa, Ontario. 1-32.

Christian, G. A. (2003). Person and Environment: Reflections on the roots of environmental psychology.

Clark, D. A., Lee, D. S., Freeman, M. M. R., \& Clark, S. G. (2008). Polar bear conservation in Canada: defining the policy problems. Arctic, 61, 347-360. https://doi.org/10.14430/arctic43

Clark, N., \& Lovell, R. (2014). Is conserving biodiversity the key to good mental health? European Centre for Environment and Human Health, University of Exeter. The Conservation, 1-2. Retrieved from http://theconservation.com/is-conserving-biodiversity-the-key-to-good-mental-health-26667

Clark, S. G. (2011). The Policy Process: A Practical Guide for Natural Resource Professionals. Yale University Press, New Haven, CT. 
Clayton, S., \& Myers, G. (2015). Conservation Psychology: Understanding and Promoting Human Care for Nature. John Wiley \& Sons, Hoboken, NJ.

Clayton, S., Litchfield, C., \& Geller, E. S. (2013). Psychological science, conservation, and environmental sustainability. Front. Ecol. Environ. 11, 377-382. https://doi.org/10.1890/120351

CNRS. (2000). Lawasera Tropical Forest of Bangladesh. Rapid Rural Appraisal (RRA) Findings. Center for Natural Resources Studies, Dhaka, Bangladesh. 1-25.

Coad, L., Campbell, A., Miles, L., \& Humphries, K. (2008). The costs and benefits of protected areas for local livelihoods: a review of the current literature. Working Paper. United Nations Environment Program World Conservation Monitoring Centre. 1-45.

Cox, M. (2015). A basic guide for empirical environmental social science. Ecology and Society, 20(1), 63. https://doi.org/10.5751/ES-07400-200163

Cranston, K. A. (2016). A brief history of conservation psychology. Antioch University, New England, USA.124. Retrieved from http://www.kaylacranston.com/learn-more.html

Curran, D. (2015). Water law as a watershed endeavour: federal inactivity as an opportunity for local initiative. $J$. Environ. Law Pract., 28, 53-87.

De Young, R. (2013). Environmental Psychology Overview. In A. H. Huffman, \& S. Klein (Eds.), Green Organizations: Driving Change with IO Psychology (pp. 17-33). NY: Routledge.

Decker, D. J., Riley, S. J., \& Siemer, W. F. (2012). Human Dimensions of Wildlife Management. JHU Press, Baltimore, MD.

Dierking, L. D., \& Falk, J. H. (1994). Family behavior and learning in informal science settings: a review of the research. Sci. Educ., 78, 57-72. https://doi.org/10.1002/sce.3730780104

DoE. (2016). National Biodiversity Strategy and Action Plan of Bangladesh 2016-2021. Department of Environment (DoE), Ministry of Environment and Forests (MoEF), Government of the People's Republic of Bangladesh, Dhaka, Bangladesh, ver2, 1.

Donovan, \& Rossiter, J. (1982). Store Atmosphere: An Environmental Psychology Approach. Journal of Retailing, 58(1), 34-57.

EC (European Commision). (2015). The Mid-term Review of the EU Biodiversity Strategy to 2020. Report from the Commission to the European Parliament and the Council, Brussels. Com, 478, 1-19.

Edgar, G. J., Stuart-Smith, R. D., Willis, T. J., Kininmonth, S., Baker, S. C., Banks, S., ... Thomson, R. J. (2014). Global conservation outcomes depend on marine protected areas with five key features. Nature, 506(7487), 216-220. https://doi.org/10.1038/nature13022

Elliott, E. D. (1994). Environmental TQM: Anatomy of a Pollution Control Program That Works! 92. Michigan Law Review, 47, 1840-1846. https://doi.org/10.2307/1289614

Ellis, E. C., Goldweijk, K., Siebert, S., Lightman, D., \& Ramankutty, N. (2010). Anthropogic Transformation of the Biomes 1700 to 2000. Global Ecology and Biogeography, 19, 589-606. https://doi.org/10.1111/j.1466-8238.2010.00540.x

EPI. (Environmental Performance Index). (2015). Global Environmental Performance Index 2014. USA., 1-5.

Evans, K., \& Guariguata, M. R. (2008). Participatory monitoring in tropical forest management: a review of tools, concepts and lessons learned. Centre for International Forestry Research, Bogor, Indonesia.

Faber-Langendoen, D., Hedge, C., Kost, M., Thomas, S., Smart, L., Smyth, R., ... Menard, S. (2012). Assessment of wetland ecosystem condition across landscape regions: a multi-metric approach. Part A. Ecological Integrity Assessment overview and field study in Michigan and Indiana. U.S. Environmental Protection Agency report EPA/600/R-12/021a, Washington, D.C.

Faber-Langendoen, D., Rocchio, J., Thomas, S., Kost, M., Hedge, C., Nichols, B., ... Muldavin, E. (2012). Assessment of wetland ecosystem condition across landscape regions: a multi-metric approach. Part B. Ecological Integrity Assessment protocols for rapid field methods (L2). U.S. Environmental Protection Agency report EPA/600/R-12/021b, Washington, D.C.

Falk, J. H. (2005). Free-choice environmental learning: framing the discussion. Environ. Educ. Res., 11, 265-280. https://doi.org/10.1080/13504620500081129 
Ferraro, P. J., Hanauer, M. M., Miteva, D. A., Canavire-Bacarreza, G. J., Pattanayak, S. K., \& Sims, K. R. E. (2013). More strictly protected areas are not necessarily more protective: evidence from Bolivia, Costa Rica, Indonesia, and Thailand. Environmental Research Letters, 8, 025011. https://doi.org/10.1088/1748-9326/8/2/025011

Fortmann L. (2008). Participatory research in conservation and rural livelihoods: doing science together. Wiley-Blackwell, Chichester, United Kingdom.

Gardner, T. A., Barlow, J., Chazdon, R., Ewers, R., Harvey, C. A., Peres, C. A., \& Sodhi, N. S. S. (2009). Prospects for tropical forest diversity in a human-modified world. Ecology Letters, 12, 1-21. https://doi.org/10.1111/j.1461-0248.2009.01294.x

Gifford, R. (2007a). Environmental psychology: Principles and practice (4th ed.). Colville, WA: Optimal Books.

Gifford, R. (2007b). Environmental psychology and sustainable development: Expansion, maturation, and challenges. Journal of Social Issues, 63, 199-212. https://doi.org/10.1111/j.1540-4560.2007.00503.x

Gifford, R. (2008). Psychology's essential role in climate change. Canadian Psychology, 49, 273-280. https://doi.org/10.1037/a0013234

Gifford, R. (2014). Environmental Psychology: Principles and Practice. Optimal Books, Canada.

Gifford, R., Steg, L., \& Reser, J. P. (2011). Environmental Psychology. In Martin, P. R., Cheung, F. M., Knowles, M. C., Kyrios, M., Littlefield, L., Overmier, J. B., \& Prieto, J. M. (Eds.). The IAAP Handbook of Applied Psychology (1st ed., pp,440-470). Blackwell Publishing Ltd. https://doi.org/10.1002/9781444395150.ch18

Gillespie, A. (2012). Science, values and people: the three factors that will define the next generation of international conservation agreements. Transnatl. Environ. Law, 1, 169-182. https://doi.org/10.1017/S204710251100001X

Global Risk Report. (2016). Biodiversity Loss and Ecosystem Collapse: Some Countries in South-East Asia. Global Risks Report 2016, 11th Edition. World Economic Forum, Geneva, Switzerland, 1-103.

Gorenflo, L. J., \& Brandon, K. (2006). Key human dimensions of gaps in global biodiversity conservation. Bioscience, 56(9), 723-731. https://doi.org/10.1641/0006-3568(2006)56[723:KHDOGI]2.0.CO;2

Grob, A. (1995). A structural model of environmental attitudes and behavior. Journal of Environmental Psychology, 15(3), 209-220. https://doi.org/10.1016/0272-4944(95)90004-7

Gujit I. (1999). Participatory monitoring and evaluation for natural resource management and research. Natural Resources Institute, Chatham, United Kingdom, 1-22.

Heimlich, J. E. (2010). Environmental education evaluation: Reinterpreting education as a strategy for meeting mission. Evaluation and Program Planning, 33, 180-185. https://doi.org/10.1016/j.evalprogplan.2009.07.009

Hidalgo, M. C., \& Hernandez, B. (2001). Place attachment: Conceptual and empirical questions. Journal of Environmental Psychology, 21, 310-319. https://doi.org/10.1006/jevp.2001.0221

Hines, J. M., Hungerford, H. R., \& Tomera, A. N. (1987). Analysis and synthesis of research on responsible environmental behavior: a meta-analysis. Journal of Environmental Education, 18, 1-8. https://doi.org/10.1080/00958964.1987.9943482

Hockings, M., Stolton, S., Leverington, F., Dudley, N., \& Courrau, J. (2006). Evaluating effectiveness: a framework for assessing the management effectiveness of protected areas (2nd ed.). International Union for the Conservation of Nature, Gland, Switzerland, 1-121. https://doi.org/10.2305/IUCN.CH.2006.PAG.14.en

Hockings, M., Stolton, S., Leverington, F., Dudley, N., \& Courrau, J. (2006). Evaluating Effectiveness: A Framework for Assessing the Management Effectiveness of Protected Areas (2nd ed.). IUCN, Gland, Switzerland. https://doi.org/10.2305/IUCN.CH.2006.PAG.14.en

Holden, A. (2016). Environment and Tourism (3rd ed.). Routledge, London, UK, 1-10. https://doi.org/10.4324/9781315767659

Hornik, J., Cherian, J., Madansky, M., \& Narayana, C. (1995). Determinants of recycling behavior: A synthesis of research results. Journal of Socio-Economics, 24, 105-127. https://doi.org/10.1016/1053-5357(95)90032-2 
Hossain, M. K. (2001). Overview of the forest biodiversity in Bangladesh. In: Assessment, conservation and sustainable use of forest biodiversity (CBD Technical Series no. 3). Secretariat of the Convention on Biological Diversity, Montreal, 33-35.

Hungerford, H. R., \& Volk, T. L. (1990). Changing learner behavior through environmental education. Journal of Environmental Education, 21, 8-21. https://doi.org/10.1080/00958964.1990.10753743

IPAC. (2012). Degree of Pressures and Threats to Protected Areas. Integrated Protected Area Co-management (IPAC). State of Bangladesh's Forest Protectedv Areas' 2010. International Resources Group, BFD-USAID, 39-40.

Jacobson, S. K. (1987). Conservation education programs: Evaluate and improve them. Environmental Conservation, 14, 201-206. https://doi.org/10.1017/S0376892900016398

Jalil, M. A. (2009). Site Level Appraisal for Protected Area Co-management: Lawachara National Park. International Resources Group, USAID and Bangladesh Forest Department, Ministry of Environment and Forests, Government of People's Republic of Bangladesh.

Juffe, B. D., Burgess, N. D., Bingham, H., Belle, E. M. S., de Lima, M. G., Deguignet, M., ... Kingston, N. (2014). Protected Planet Report 2014. UNEP-WCMC: Cambridge, UK.

Kaiser, F. G., Ranney, M., Hartig, T., \& Bowler, P. A. (1999). Ecological Behavior, Environmental Attitude, and Feelings of Responsibility for the Environment. European Psychologist, 4(2), 59-74. https://doi.org/10.1027//1016-9040.4.2.59

Kals, E., \& Maes, J. (2002). Sustainable development and emotions. In P. Schmuck, \& W. Schultz (Eds.), Psychology of sustainable development (pp. 97-122). Norwell, MA: Kluwer. https://doi.org/10.1007/978-1-4615-0995-0_6

Khafagi, I., Zakaria, A., Dewedar, A., \& El-Zahdany, K. (2006). A Voyage in the World of plants as mentioned in the Holy Quran. International Journal of Botany, 2(3), 242-251. https://doi.org/10.3923/ijb.2006.242.251

Kinuthia, W. (2008). Another Spotlight on the Continent: TechTrends in Africa. Education Resource Information Centre (ERIC). TechTrends, 52(4), 1-3. Retrieved March 10, 2017, from www.eric.ed.gov/?id=EJ809329

Kittinger, J. N., Finkbeiner, E. M., Glazier, E. W., \& Crowder, L. B. (2012). Human dimensions of coral reef social-ecological systems. Ecology and Society, 17(4), 17. https://doi.org/10.5751/ES-05115-170417

Kothari, C. R. (Ed.). (2004). Research Methodology: Methods and Techniques (2nd ed.). New Age International Publishers, 95-111.

Kruse, L. (1995). Globale Umweltver"anderungen: eine Herausforderung f'ur die Psychologie wGlobal environmental changes: a challenge for psychologyx. Psychologische Rundschau, 46, 81-92.

Kuhar, C. W., Bettinger, T. L., Lehnhardt, K., Tracy, O., \& Cox, D. (2010). Evaluating for long-term impact of an environmental education program at the Kalinzu Forest Reserve, Uganda. Am. J. Primatol., 72, 407-413. https://doi.org/10.1002/ajp.20726

Lafferty, W. M., \& Meadowcroft, J. (Eds.). (1996). Democracy and the Environment: Problems and Prospects. Cheltenham, Edward Elgar, 1-276.

Liaison Unit Vienna. (2000). General Declarations and Resolutions: Adopted at the Ministerial Conferences on the Protection of Forests in Europe. Vienna, Ministerial Conference on the Protection of Forests in Europe., $1-88$.

Lindenmayer, D. B., \& Fischer, J. (2007). Tackling the habitat fragmentation panchreston. Trends in Ecology and Evolution, 22, 127-132. https://doi.org/10.1016/j.tree.2006.11.006

Lloyd, K. E. (1980). Do as I say, not as I do. New Zealand Psychologist, 9, 1-8.

Lockwood, M. (2010). Good governance for terrestrial protected areas: a framework, principles and performance outcomes. J. Environ. Manag., 91, 754-766. https://doi.org/10.1016/j.jenvman.2009.10.005

Lundqvist, L. J. (1996). Environmental Politics in the Nordic Countries: Policy Organization and Capacity. In P. M. Christiansen (Ed.), Governing the Environment: Politics, Policy and Organization in the Nordic Countries. Nordic Council of Ministers, Copenhagen, 5.

MacKinnon, J., MacKinnon, K., Child, G., \& Thorsell, J. (Eds.). (1986). Managing Protected Areas in the Tropics. IUCN, Gland, Switzerland, 1-295. 
Manfredo, M. J. (2008). Who Cares About Wildlife?: Social Science Concepts for Exploring Human-Wildlife Relationships and Conservation Issues. Springer Science \& Business Media, New York, NY. https://doi.org/10.1007/978-0-387-77040-6_1

Manfredo, M. J., Vaske, J. J., Rechkemmer, A., \& Duke, E. A. (Eds.). (2014). Understanding Society and Natural Resources. Springer Netherlands, Dordrecht. https://doi.org/10.1007/978-94-017-8959-2

Manfredo, M., Teel, T. L., Gavin, M. C., \& Fulton, D. (2014). Considerations in representing human individuals in social-ecological models. In M. J. Manfredo, J. J. Vaske, A. Rechkemmer \& E. A. Duke (Eds.), Understanding Society and Natural Resources: Forging New Strands of Integration Across the Social Sciences (pp. 137-158). Springer, New York, NY. https://doi.org/10.1007/978-94-017-8959-2_7

Martin, W. E., Wise Bender, H., \& Shields, D. J. (2000). Stakeholder objectives for public lands: Rankings of forest management alternatives. Journal of Environmental Management, 58, 21-32. https://doi.org/10.1006/jema.1999.0313

Massada, A. B., Radeloff, V. C., \& Steward, S. I. (2014). Biotic and Abiotic Effects of Human Settlements in the Wildland-Urban Interface. BioScience, 64(5), 429-437. https://doi.org/10.1093/biosci/biu039

McDuff, M., \& Jacobson, S. (2000). Impacts and future directions of youth conservation organizations: wildlife clubs in Africa. Wildl. Soc. Bull, 28, 414-425.

McNeely, J. A. (1994). Protected areas for the 21 st century: working to provide benefits to society. Biodiversity and Conservation, 3, 390-405. https://doi.org/10.1007/BF00057797

MEA (Millennium Ecosystem Assessment). (2005). Ecosystems and Human Wellbeing: Synthesis. Island Press, Washington, D.C.

Menzel, S., \& Teng, J. (2009). Ecosystem services as a stakeholder-driven concept for conservation science. Conservation Biology, 24(3), 907-909. https://doi.org/10.1111/j.1523-1739.2009.01347.x

Miah, M. R., Sayok, A. K., Sarok, A., \& Uddin, M. B. (2017). Towards Dynamic Policy Instruments for Enhancing Biodiversity Conservations in National Parks: A Case Study on Bangladesh and Sarawak, Malaysia. Borneo Journal of Resource Science and Technology, 7(1), 11-30. https://doi.org/10.33736/bjrst.391.2017

Michael, S., Quinn, \& Alexander, S. M. (2006). Information Technology and the Harmonization of Biodiversity in Protected Areas. In K. S. Hanna, D. A. Clark, \& D. S. Slocombe (Eds.), Transforming Parks and Protected Areas: Policy and Governance in a Changing World (Chapter 4., pp. 66), Routledge- Taylor \& Francis Group, New York, USA. Retrieved June 10, 2017, from http://people.duke.edu/ lcampbe/docs_lmc/Campbell_2008_ParksProtectedAreas.pdf

Mora, C., \& Sale, P. (2011). Ongoing global biodiversity loss and the need to move beyond protected areas: a review of the technical and practical shortcomings of protected areas on land and sea. Marine Ecology Progress Series, 434, 251-266. https://doi.org/10.3354/meps09214

Moran, E. (2010). Environmental Social Science: Human - Environment Interactions and Sustainability. John Wiley \& Sons, West Sussex, UK. 1-232. https://doi.org/10.1002/9781444319057

MP (Management Plan). (2006). Management Plan for Lawachara National Park. Nishorgo Support Project, Bangladesh Forest Department, Government of People's Republic of Bangladesh, 1-172.

NACOM. (2003). Co-management of Tropical Forest Resources of Bangladesh: Secondary Data Collection for Pilot Protected Areas-Lawachara National Park. USAID-Bangladesh and Ministry of Environment and Forests (MoEF). 1-51.

Nature Surve. (2012). Rapid measurement of ecological integrity: measuring habitat/biodiversity outcomes across jurisdiction and scales. Power point presentation "Ecological integrity monitoring framework". Retrieved June 10, 2017, from http://conservatioregistry.org/projects/217753

Newhouse, N. (1990). Implications of attitude and behavior research for environmental conservation. Journal of Environmental Education, 22, 26-32. https://doi.org/10.1080/00958964.1990.9943043

Newsome, D., \& Hughes, M. (2018). The Contemporary conservation reserve visitor phenomenon. Biodiversity Conservation, 27, 521-529. https://doi.org/10.1007/s10531-017-1435-4

Nickerson, R. S. (2003). Psychology and environmental change. Mahwah, NJ: Erlbaum. 
NPFF (National Park Facts and Figures). (2016, August). Land area covered by National Parks. Physical facts and figures. UK. Retrieved from http://www.nationalparks.gov.uk/students/whatisanationalpark/factsandfi

NSP. (2005). Site Strategy for Lawachara National Park. Nishorgo Support Project. BFD-USAID/IRG, Dhaka.

NSP. (2006). Simplified Management Guidelines of Lawachara National Park. Nishorgo Support project- funded by USAID. Bangladesh Forest Department, Dhaka. 1-13.

O'Neill, M., Riscinto-Kozub, K., \& Van Hyfte, M. (2010). Defining visitor satisfaction in the context of camping oriented nature-based tourism-the driving force of quality. Journal of Vacation Marketing, 16(2), 141-156. https://doi.org/10.1177/1356766710364541

Owens, S., \& Hope, C. W. (1989). Energy and Environment: The Challenge of Integrating European Policies. Energy Policy, 17(2), 97-102. https://doi.org/10.1016/0301-4215(89)90087-6

Owley, J. (2015). Keeping track of conservation. Ecol. Law Q., 42, 79-138.

Papallacta Declaration. (2006). Conservation Connectivity. General Assembly, United Nations, Papallacta Declaration on 7 November, 2006 at Termas de Papallacta, Ecuador, 1-5.

Parrish, J. D., Braun, D. P., \& Unnasch, R. S. (2003). Are we conserving what we say we are? Measuring ecological integrity within protected areas. BioScience, 53, 851-860. https://doi.org/10.1641/0006-3568(2003)053[0851:AWCWWS]2.0.CO;2

Pearson, E. (2013). Conservation Psychology: A Gap in Current Australian Undergraduate Psychology Education?. Sustainability, 5, 1266-1281. https://doi.org/10.3390/su5031266

Pett, T. J., Shwartz, A., Irvine, K. N., Dallimer, M., \& Davies, Z. (2016). Unpacking the People-Biodiversity Paradox: A Conceptual Framework. BioScience, $X X(\mathrm{x}), 1-8$. Retrieved from http://bioscience.oxfordjournals.org

Pfeifer, M., Burgess, N. D., Swetnam, R. D., Platts, P. J., Willcock, S., \& Marchant, R. (2012). Protected areas: mixed success in conserving East Africa's evergreen forests. PLoS ONE, 7(e39337). https://doi.org/10.1371/journal.pone.0039337

Poffenberger, M. (Ed.). (2000). Communities and Forest Management in South Asia, IUCN, Gland, Switzerland, 161.

Pol, E. (2006). Blueprints for a history of environmental psychology (I): From first birth to American transition. Medio Ambientey Comportamiento Humano, 7(2), 95-113.

Pomeroy, R. S., Parks, J. E., \& Watson, L. M. (2004). How Is your MPA Doing? A Guidebook of Natural and Social Indicators for Evaluating Marine Protected Area Management Effectiveness. IUCN, Gland, Switzerland. https://doi.org/10.2305/IUCN.CH.2004.PAPS.1.en

Portney, P. R. (1990). Public Policies for Environmental Protection, Resources for the Future 1616 P Street, N.W., Washington, D.C. 20036, 53.

Proshansky, H. M. (1987). The field of environmental psychology: securing its future. In D. Stokols, \& I. Altman (Eds.), Handbook of Environmental Psychology. New York: John Wiley \& Sons.

Proshansky, H., Fabian, A., \& Kaminoff, R. (1983). Place Identity: Physical World Socialization of the Self. Journal of Environmental Psychology, 3(1), 57-83. https://doi.org/10.1016/S0272-4944(83)80021-8

Pulsford, I., Lindermayer, D., Wyborn, C., Lausche, B., Worboys, G. L., Vasilijevic, M., \& Lefroy, T. (2015). Connectivity Conservation Management. In G. L. Worboys, M. Lockwood, A. Kothari, S. Feary, \& I. Pulsford (Eds.), Protected Area Governance and Management (pp. 851-888). ANU Press, Canberra, Australia.

Ramkissoon, H., Smith, L. D. G., \& Weiler, B. (2013). Relationships between place attachment, place satisfaction and pro-environmental behaviour in an Australian national park. Journal of Sustainable Tourism, 21(3), 434-457. https://doi.org/10.1080/09669582.2012.708042

Ramkissoon, H., Weiler, B., \& Smith, L. D. G. (2011). Place attachment and pro-environmental behaviour in national parks: the development of a conceptual framework. Journal of Sustainable Tourism, 1-20. https://doi.org/10.1080/09669582.2011.602194

Reuters. (2007). Bangladesh Elephant dies in fight with another. Environment chapter, Cox's Bazar, Bangladesh (Reuters), 22 March, 2007. 
RIMS (Resource Information Management Systems). (2015). RIMS Unit, Bangladesh Forest Department, Ban Bhaban, Ministry of Environment and Forests, Government of the People's Republic of Bangladesh, Dhaka., $1-3$.

Ring, I., \& Schroter-Schlaack, C. (2011). Instrument Mixes for Biodiversity Policies. POLICYMIX Report No. 2/2011. Helmholtz Centre for Environmental Research-UFZ, Leipzig.

Rose, T., Kremen, C., Trupp, A., Herren, B. G., Graub, B., \& Azzu, N. (2014). Policy Mainstreaming of Biodiversity and Ecosystem Services with a Focus on Pollination. Policy Analysis Paper. "Policies for Pollination Management" Workshop held in Nairobi, Kenya on 23-24 September, 2013. ISBN 978-92-5-108666-7, FAO, 1-66.

Rufford. (2014, August 19). Final Report. Small Grant for Nature Conservation Project, The Rufford Foundation, $\begin{array}{lllll}U K . & \text { Retrieved } & \text { June } & 10, & \text { from }\end{array}$ http://www.rufford.org/files/75.07.05\%20Detailed\%20Final\%20Report.doc

Rutherford, M. B., Gibeau, M. L., Clark, S. G., \& Chamberlain, E. C. (2009). Interdisciplinary problem solving workshops for grizzly bear conservation in Banff National Park, Canada. Policy Sci., 42, 163-187. https://doi.org/10.1007/s11077-009-9075-5

Salata, T. L., \& Ostergren, D. M. (2010). Evaluating forestry camps with national standards in environmental education: a case study of the Junior Forester Academy, Northern Arizona University. Appl. Environ. Educ. Commun., 9, 50-57. https://doi.org/10.1080/15330150903566521

Salem, B. B. (2003). Application of GIS to biodiversity monitoring. Journal of Arid Environments, 54, 91-114. https://doi.org/10.1006/jare.2001.0887

Saunders, C. D. (2003). The emerging field of conservation psychology. Human Ecology Review, 10, $137-149$.

Scannell, L., \& Gifford, R. (2010a). Defining place attachment: A tripartite organizing framework. Journal of Environmental Psychology, 30(1), 1-10. https://doi.org/10.1016/j.jenvp.2009.09.006

Scannell, L., \& Gifford, R. (2010b). The relations between natural and civic place attachment and pro-environmental behavior. Journal of Environmental Psychology, 30(3), $289-297$. https://doi.org/10.1016/j.jenvp.2010.01.010

Schultz, P. W., Oskamp, S., \& Mainieri, T. (1995). Who recycles and when? A review of personal and situational factors. Journal of Environmental Psychology, 15, 105-121. https://doi.org/10.1016/0272-4944(95)90019-5

SF (Sarawak Forestry). (2016). Batang Ai National Park. Sarawak, Malaysia. Retrieved June 10, 2017, from http://www.sarawakforestry.com/htm/snp-np-batangai.html

Simonton, D. K. (1988). Scientific Genius: A Psychology of Science. Cambridge University Press, USA. 1-229.

Smythe, P. C., \& Brook, R. C. (1980). Environmental concerns and actions: A social-psychological investigation. Canadian Journal of Behavioral Science, 12, 175-186. https://doi.org/10.1037/h0081025

Solh, M., Amri, A., Ngaido, T., \& Valkoun, J. (2003). Policy and education reform needs for conservation of dryland biodiversity. Journal of Arid Environments, 54, 5-13. https://doi.org/10.1006/jare.2001.0896

Solihu, A. K. H. (2014). Valuing Biodiversity: A Quranic Account. International Journal of Environmental Science and Development, 5(3), 244-250. https://doi.org/10.7763/IJESD.2014.V5.486

Soulé, M. E., \& Sanjayan, M. A. (1998). Conservation targets: do they help? Science, 279, $2060-2061$. https://doi.org/10.1126/science.279.5359.2060

Steg, L., van den Berg, A. E., \& de Groot, J. I. M. (2013). Environmental Psychology: An Introduction (BPS Textbooks in Psychology). Chichester, U. K.: Wiley-Blackwell. 1-398. https://doi.org/10.1002/9781119241072.ch1

Stern, E. (1982). Bus services in rural areas. Environment and Behavior, 14, 94-112. https://doi.org/10.1177/0013916582141006

Stern, P. C. (1978). When do people act to maintain common resources? A reformulated psychological question for our times. International Journal of Psychology, 13, 149-158. https://doi.org/10.1080/00207597808246619

Stern, P. C. (1992). Psychological dimensions of globalenvironmental change. Annual Reviews of Psychology, 43, 269-302. https://doi.org/10.1146/annurev.psych.43.1.269 
Stern, P. C. (2000). Toward a coherent theory of environmentally significant behavior. Journal of Social Issues, 56(3), 407-424. https://doi.org/10.1111/0022-4537.00175

Sutherland, W. J., Pullin, A. S., Dolman, P. M., \& Knight, T. M. (2004). The need for evidence-based conservation. Trends in Ecology \& Evolution, 19, 305-308. https://doi.org/10.1016/j.tree.2004.03.018

Teel, T. L., \& Manfredo, M. J. (2010). Understanding the diversity of public interests in wildlife conservation. Conservation Biology, 24, 128-139. https://doi.org/10.1111/j.1523-1739.2009.01374.x

Theobald, D. M., \& Hobbs, N. T. (2002). A Framework for Evaluating Land Use Planning Alternatives: Protecting Biodiversity on Private Land. Conservation Ecology, 6(1), 5. https://doi.org/10.5751/ES-00379-060105

Thomas, R. E. W., Teel, T. L., \& Bruyere, B. L. (2014). Seeking excellence for the land of paradise: Integrating cultural information into an environmental education program in a rural Hawai'ian community. Evaluating environmental education. Stud. Educ. Eval., 41, 58-67. https://doi.org/10.1016/j.stueduc.2013.09.010

Tlili, S. (2012). Animals in the Quran. Cambridge, Cambridge University Press, 65-256.

Tonge, J., Moore, S. A., \& Taplin, R. (2011) Visitor satisfaction analysis as a tool for park managers: a review and case study. Annals of Leisure Research, 14(4), 289-303. https://doi.org/10.1080/11745398.2011.639339

Treves, N. L., Holland, M. B., \& Brando, K. (2005). The Role of Protected Areas in Conserving Biodiversity and Sustaining Local Livelihood. Annual Review of Environmental Resources, 30, 219-252. https://doi.org/10.1146/annurev.energy.30.050504.164507

Tyrrell, T. D., \& Alcorn, J. B. (2011). Analysis of possible indicators to measure impacts of REDD+ on biodiversity and on indigenous and local communities: A report to the Convention on Biological Diversity. Tentera, Montreal, Canada. Retrieved May 8, 2016, from https://www.cbd.int/doc/meetings/sbstta/sbstta-16/information/sbstta-16-inf-21-en.pdf

UNEP. (2004). Economic Instruments in Biodiversity Related Multilateral Environmental Agreements. UNEP/ETB/2003/10, United Nations Publications. 1-117.

UNESCO-UNEP. (1976). The Belgrade charter. Connect UNESCO-UNEP Environ. Educ. Newsl. 1, 1-2.

Unnasch, R. S., Braun, D. P., Comer, P. J., \& Eckert, G. E. (2009). The Ecological Integrity Assessment Framework: assessing the ecological integrity of biological and ecological resources of the national park system. Report to the National Park Service. Retrieved June 10, 2017, from http://www.sound-science.org/NPS_Ecological\%20Integrity\%20FRamework.pdf

UNTWO. (2017). UNWTO World Tourism Barometer, United Nations World Tourism Organisation, Madrid, Spain., 1-7.

Vaccaro, I., Smith, E. A., \& Aswani, S. (Eds.). (2010). Environmental Social Sciences: Methods and Research Design. Cambridge University Press, Cambridge, UK. https://doi.org/10.1017/CBO9780511760242

Van Hoorick, G. (2014). Compensatory measures in European nature conservation law.Utrecht Law Rev., 10, 161-171. https://doi.org/10.18352/ulr.276

Vaske, J. J., \& Manfredo, M. J. (2012). Social Psychological Considerations in Wildlife Management. In D. J. Decker, S. J. Riley, \& W. F. Siemer (Eds.), Human Dimensions of Wildlife Management (pp. 43-57). JHU Press, Baltimore, MD.

Vickerman, S., \& Kagan, J. (2014). Assessing ecological integrity across jurisdiction and scales. Retrieved June 10, 2017, from http://www.defenders.org/sitesdefault/files/publications/assessing-ecological-integrity-across-jurisdictions-a nd-scales.pdf

Walter, E., McGonigle, R. M., \& McKay, C. (2000). Fishing around the Law: The Pacific Salmon Management System as a Structural Infringement of Aboriginal Rights. McGill L. J., 45, 263.

Weale, A. (1992). The New Politics of Poluution: Issues in Environmental Politics. Manchester University Press, Manchester.

Wellman, K. F., Biedenweg, K., \& Wolf, K. (2014). Social sciences in Puget sound recovery. Coastal Management, 42(4), 298-307. https://doi.org/10.1080/08920753.2014.923129

West, P., Igoe, J., \& Brockington, D. (2006). Parks and peoples: the social impact of protected areas. Annual Review of Anthropology, 35, 251-277. https://doi.org/10.1146/annurev.anthro.35.081705.123308 
White, R. (2011). Transnational Environmental Crime: Toward an Eco-global Criminology. Routledge, London, UK. https://doi.org/10.1201/9781420085525-c9

Willamette Partnership. (2011). Measuring up: synchronizing biodiversity measurement systems for markets and other incentive programs. Retrieved from http://willamettepartnership.org/wp-content/uploads/2015/04/Measureing-Up-w-appendices-final.pdf

Wilson, E. O. (Ed.). (1988). Biodiversity. National Academy Press, Washington D.C., USA.

Worboys, G. I., \& Mackey, B. (2013). Connectivity Conservation Initiatives: A National and International Perspectives. In J. Fitzsimons, I. Pulsford, \& G. Wescott (Eds.) Linking Australia's Landscapes: Lessons and opportunities from large scale Conservation Network (pp. 7-22). CSIRO publishing, Melbourne.

Zhang, C. Z., Xu, H. G., Su, B. T., \& Ryan, C. (2009). Visitors' perceptions of the use of cable cars ans lifts in Wulingyuan World Heritage Site. China Journal Sustainable Tour, 17(5), 551-566. https://doi.org/10.1080/09669580902780745

\section{Copyrights}

Copyright for this article is retained by the author(s), with first publication rights granted to the journal.

This is an open-access article distributed under the terms and conditions of the Creative Commons Attribution license (http://creativecommons.org/licenses/by/4.0/). 